\title{
A população no passado colonial brasileiro: mobilidade versus estabilidade*
}

\section{Sérgio Odilon Nadalin*}

\section{A ênfase nas migrações e no povoamento}

Ao sugerir como se deveria escrever a História do Brasil, em tese oferecida ao Instituto Histórico e Geográfico do Brasil, Carl Friedrich Martius propunha histórias "regionais": "deviam ser tratadas conjunctamente aquellas porçôes do paiz que, por analogia da sua natureza phisica, pertencem umas às outras". ${ }^{1}$ Essas diretrizes foram aprofundadas mais tarde por Capistrano de Abreu, ao relacionar os caminhos coloniais e o povoamento do território, ${ }^{2}$ e João Ribeiro, que indicou cinco "células fundamentais", cujas histórias fizeram-se ao mesmo tempo por "múltiplos estímulos" em diferentes pontos. ${ }^{3} \mathrm{Ou}$ seja, a população que se expandia partia dos seguintes pontos iniciais da costa: São Paulo, Rio de Janeiro, Bahia, Pernambuco e Maranhão. Consistia

[...] na distensão das populações sobre os territórios contíguos, sem que a parte que se mobilizava perdesse o contato físico, social e econômico com o núcleo inicial. Assim se criavam conjuntos regionais com unidade territorial e comunitária, formados de um centro dominante e comunidades subordinadas. ${ }^{4}$

As lições de Martius traduzem-se numa primeira apreensão, na perspectiva da história demográfica: a história do Brasil é uma história de migraçôes. Ou seja, os deslocamentos populacionais que resultaram na "colonização" e conquista do território foram realizados por uma população

\footnotetext{
*Artigo recebido em maio de 2003 e aprovado em junho de 2003.

${ }^{* *} \mathrm{O}$ autor agradece a leitura atenta e as observaçōes do Professor Luiz Geraldo Santos Silva, como também o apoio do Instituto de Pesquisa Econômica Aplicada (IPEA).
} 
migrante, bandeirantes de "guerra" e de "povoamento", aventureiros e empreendedores de castas diversas, população essa constituída também dos cativos, africanos e seus descendentes negros, mulatos e cafuzos. Essa história de deslocamentos populacionais contemplou, no seu processo, a captura e/ou destruição física e cultural do indígena.

As lições do naturalista bávaro também poderiam ser apreendidas no sentido de problematizar os regimes demográficos numa perspectiva cultural, ${ }^{5}$ característicos da colônia. De fato - colocando provisoriamente de lado os "sistemas demográficos" e abstraindo os denominadores comuns oriundos do próprio sistema colonial -, o esquema aponta para diferenciaçóes locais. Assim, uma vasta região de fronteira, ao Sul, foi povoada sob os impulsos oriundos das ações políticas comandadas do Rio de Janeiro: a ordem era consolidar o domínio português até o Prata e, ao Oeste, da parte meridional da capitania de São Paulo até as Missões e as Vacarias do Rio Grande. Ainda na vasta região, mas abrindo-se ao Oeste e ao Centro (as Minas Gerais, Goiás e Mato Grosso), comandava a “aventura” paulista, motivada pela profusão de aborígines no interior e pela busca de metais preciosos. Atrás deles vieram miríades de colonos de todas as partes, inclusive imigrantes portugueses, ${ }^{6}$ instalando-se, aqui, uma economia típica de mineração, entremeada por agricultura de subsistência ali, e a criação de gado acolá. Aliás, o gado, levando o homem - parodiando Capistrano -, foi o estímulo essencial para o ralo - porém contíguo - "povoamento" dos sertôes a partir da Bahia e de Pernambuco, incluindo as regióes desde Ilhéus até Sergipe e chegando ao Piauí e Maranhão, de um lado e, de outro, povoando a Paraíba, o Rio Grande do Norte, Ceará e Alagoas, completando-se desta forma a união das três grandes bacias da América do Sul. ${ }^{7}$ Povoamento sui generis, pois expulsou e aniquilou os indígenas que primitivamente habitavam a região. Finalmente, lá no Setentrião do Amazonas, no Pará e no Maranhão, vislumbra-se o imperativo da busca das "drogas do sertão", acessada a partir da vasta rede hidrográfica regional.

De modo que esses ensinamentos implicitam questões, tais como a definição de "restrições e oportunidades demográficas" semelhantes e diferenciadas pelo regime colonial em seus distintos aspectos locais e dada uma estruturação econômica própria; e, de modo geral, como, no interior de prováveis sistemas regionais, articulavam-se camadas e grupos sociais com 
regimes demográficos restritos. ${ }^{8}$ Há que se considerar, nas suas formulações, as enormes dimensões do Império Português e o próprio tamanho do território "brasileiro" - que, desde logo, não tiveram como limite a linha de Tordesilhas -, envolvendo distintas estratégias coloniais. Da mesma forma, o tempo extremamente largo no qual se insere o tema, desde os séculos XVI até o XVIII, espraiando-se inclusive até 1850, após a Independência. Também há que se observar a complexidade do problema posto não só pela tese de Martius, mas pela própria realidade colonial e, finalmente, a ausência quase absoluta de dados empíricos que sustentem uma melhor abordagem da problemática.

Tudo isso somado levou à adoção, neste artigo, de algumas estratégias, para evitar, inclusive, que se caia na vala comum das explicaçôes e generalizações fáceis ligadas à transição demográfica. Porque parece-nos um lugar comum dizer que o regime demográfico da época colonial caracterizava-se por altas taxas de fecundidade e por altas taxas de mortalidade permitindo, no saldo final, um certo crescimento natural combinado com alguma imigração - mesmo que se complexifique o modelo, articulando este comportamento populacional com uma mobilidade interna bastante importante.

Na perspectiva em que o tema da história do Brasil é abordado, compreende-se por que foi decidido centrar o foco no século XVIII. Toda a aventura colonial desemboca no setecentos e, num certo prisma, termina com o desembarque da corte portuguesa em 1808. O Brasil deixara de ser dependente da Metrópole, para ser sede do Reino - e, alguns anos mais, um país independente. Mas continua a ser "colônia" no seu edifício institucional e estrutural, sem considerar outras questóes, como, por exemplo, a dependência portuguesa da Inglaterra. Essa temporalidade é bruscamente rompida com as profundas mudanças que se desenvolvem a partir da segunda metade do século XIX. Como conseqüência, grande parte das questôes a serem desenvolvidas neste texto pode, e deve, ser generalizada pelo menos até 1850 . Da mesma forma, pode ser ampliada para um passado mais distante, em especial o século XVII, quando várias estratégias coloniais se colocam, pedindo aqui desculpas pelo lugar comum: o Brasil torna-se a jóia do império; bem ou mal, adota-se uma política de povoamento e o açúcar, complementado por outros produtos, tornava a colônia viável. ${ }^{9}$ 
Mas, como uma nação de 1,5 milhão de habitantes poderia validar sua posse com uma ocupação demográfica por imigrantes lusos, situação que seria mais e mais complicada pela demanda de mão-de-obra da cultura açucareira? Considere-se, ainda, nesse problema, o fato primordial de que os engenhos de açúcar não eram atrativos para pessoas de poucos recursos. Além da questão populacional e de capitais a serem investidos ${ }^{10}$, era necessário enfrentar uma natureza de certa maneira brutal, representada pelos trópicos, com obstáculos imprevisíveis e contra os quais um possível "colono" europeu não estaria preparado.

Como seria possível, portanto, viabilizar demograficamente a colonização? A solução adotada era coerente com a época e consistia, em síntese, numa palavra: escravidão. O termo traduzia uma mentalidade, um sistema e uma estratégia; nesse contexto é possível entender a complementaridade das açôes coloniais no Atlântico Sul, subordinando-se Angola ao fornecimento de escravos para o Brasil: os portugueses não pretendiam o povoamento da África. ${ }^{11}$

É também nesse contexto que é possível compreender a tática de povoar utilizando pessoas "sem qualidade" do continente europeu. O mundo moderno caracterizava-se - pari passu com o desenvolvimento da economia - por profundo processo de pauperização. Assim, aos homens de bem, livres e empreendedores, aos aventureiros de maior ou menor condição que se voltavam para fazer fortuna nas colônias, agregavam-se emigrantes pobres e desqualificados. O desenvolvimento dos impérios coloniais e o português não fugiu à regra - teve importante função na absorção de mendigos e vagabundos, "muitas vezes recrutados à força para fazerem serviço militar nas possessóes de além-mar". Completava o quadro uma jurisprudência que facilitava o setenciamento de pequenos transgressores com prisão e exílio: "todo navio que partia para o Brasil, India ou África trazia, sobretudo a partir do século XVII, a sua quota de degredados" [...]. ${ }^{12}$

De forma que a um sistema de povoamento com essas premissas mantida a deficiência demográfica fundamental de Portugal - soma-se o quadro de "uma miscigenação (que) se combina com a aculturação para dar lugar ao processo social da mestiçagem". ${ }^{13}$ Junto às estratégias de colonização - onde se inclui a migração forçada de, estima-se, pelo menos 3,3 milhões de africanos $-{ }^{14}$ desenvolveram-se comportamentos característicos de uma 
sociedade hierarquizada que estigmatizava as populações indígenas, os negros e os mestiços, o que era agravado pela emigração predominantemente masculina. Geralmente, as mulheres portuguesas não emigravam ou, pelo menos, não emigravam na mesma proporção que os homens $-{ }^{15}$ e, em conseqüência, os artifícios desenvolvidos no Império poderiam ser relativamente simples, embora muitas vezes cruéis. No caso do Brasil, em resumo, a preação de índios resultou, muitas vezes, na morte dos varões e na miscigenação dos portugueses com as nativas. Isso estaria de acordo com a política portuguesa de criar novas "raças" de mestiços fiéis a Portugal. ${ }^{16}$ De maneira mais ampla, estaria também de acordo com "o drama fundador de muitas comunidades históricas”, baseado na superioridade misógina da mulher sobre o homem e agravado no contexto de uma relação vencidos - os gentios da terra e os gentios da África - e vencedores. ${ }^{17}$

\section{As intenções deste artigo}

Tudo isso posto, vislumbra-se a intenção, neste artigo, de refletir sobre as características da história do Brasil, em especial no seu período colonial, tendo como via de acesso um dos seus alicerces, a base populacional. Entretanto, deve ser salientado que a sua abordagem não traduz uma história demográfica; quando muito, talvez, são indicadas diretrizes para pensar a história da população brasileira - história da população como uma versão diacrônica dos chamados "estudos populacionais".

Se a preocupação com o populacional e o demográfico é patente, o propósito maior será o de tentar colocar algumas questôes, tendo em vista a relação entre a população, as estruturas sociais e certas instituições, passando por uma economia e uma cultura peculiar à época colonial; e, é claro, considerando sua geografia. Nessa direção, o texto pretende encaminhar uma reflexão a respeito da necessidade de nuançar a tradicional assertiva de que o passado brasileiro, pré-malthusiano ${ }^{18}$, caracterizava-se por altas taxas de mortalidade e de natalidade - o que, numa generalização perigosa, não constitui uma inverdade - mas cujas ênfases encaminham à transição demográfica e a uma perspectiva teleológica da história.

Assim sendo, também procurar-se-á fugir a uma síntese que começaria com o período "pré-colombiano", desenvolvendo-se até as mudanças 
estruturais anunciadas no início do século XIX, passando, de século em século, de fase em fase, rupturas e ciclos, pelo tradicional realce na formação mestiça do povo brasileiro; ou seja, a contribuição do branco, do indígena e do negro - apresentado geralmente nessa ordem. Essa estratégia de narrativa poderia resvalar, igualmente, no sentido de uma história "linear" da população brasileira, o que não seria coerente com as intenções do artigo.

De modo que o texto pretende evidenciar um esforço em escapar de uma perspectiva historiográfica que tende, pelo fato de se centrar no Nordeste, na Bahia, no Rio, ou em São Paulo, a enfatizar o litoral. Portanto, o eixo da narrativa deverá estar centrado nos habitantes dos campos paranaenses, no quadro cronológico de um século XVIII “estendido". Mas - o leitor deve ficar bem alertado - o propósito não é, de forma alguma, fazer "história regional". O alcance deve ser buscado mais adiante, lá, na "fronteira”. Lá, no "início" do território colonial. Lá - finalmente - na intenção deste artigo, qual seja, a de refletir sobre o tema dos regimes demográficos no passado colonial brasileiro.

\section{Mobilidade versus estabilidade}

Corria o ano de 1772. Nos campos ondulados e fracamente povoados do planalto curitibano, entremeado de manchas de mata e capões de araucárias, constituía domicílio o casal Gregório Gonçalves e Anna Maria de Lima. O "rancho" onde passaram a viver foi erguido no bairro de Butiatuva, na freguesia de Curitiba. Casaram-se na Igreja Matriz de Nossa Senhora da Luz dos Pinhais, no dia 9 de setembro daquele ano. Era uma quarta-feira, de manhã. ${ }^{19}$

O casal, e os filhos que teria durante o seu ciclo matrimonial, era parte, sobretudo, de uma população incluindo brancos pobres, mestiços e vadios, que habitava e ou vagueava pelo planalto e, de forma muito parecida, em toda a colônia. Compreendiam-se nesses segmentos, um pouco por todo lugar, e de forma mais ou menos marginal, pessoas com atividades diversas, mulatos, forros e até bandidos e escravos fugidos. ${ }^{20}$ Eram o fragmento, portanto, de uma população original, algumas vezes sem "estrutura social configurada, caracterizando-se pela fluidez, pela instabilidade, pelo trabalho esporádico, incerto, aleatório". Numa sociedade que se 
estruturava em torno da escravidão e, também no Sul e outras regiōes, na criação e no comércio do gado, esses grupos ocupavam "funçôes que o escravo não podia desempenhar". ${ }^{21}$ Os "vadios", em especial, podiam ser desde pequenos proprietários, artesãos, mulatos e negros fugidos até aqueles criminosos que já vinham de Portugal ou das Ilhas com esta pecha.

Mas a história da família fluía para outra direção: à medida que solidaram seus domicílios no primeiro planalto paranaense, os componentes das "linhagens" dos Gonçalves e dos Lima - em especial, Gregório, sua mulher, filhos e filhas -, viam nascer gradativamente um sentimento de identidade que começava a florescer na região, que os distinguiam daqueles viajantes que subiam a serra, oriundos vez ou outra do litoral ou, mesmo, de além-mar. Se, no início do povoamento, Curitiba foi um apêndice do litoral, logo parcela de seus habitantes se especializaram em atividades ligadas, direta ou indiretamente, à criação e negócios de gado. Do seu lado, os habitantes da freguesia de Paranaguá - mesmo aqueles que viviam da agricultura - tinham no seu horizonte o porto e o comércio.

Pairando acima, estava lá, cada vez mais, a presença da autoridade, principalmente após a ascensão do Marquês de Pombal em Portugal (1756). De fato, ao se iniciar a segunda metade do século XVIII, inaugurava-se uma nova etapa do empreendimento português no Brasil, que culminaria no desembarque da família real, em 1808. Cimentavam-se, também dessa forma, o desaparecimento paulatino do bandeirantismo espontâneo e o desenvolvimento das atividades mineiras no centro do país. Esse também é o contexto político e militar da consolidação lusa no território, em detrimento dos espanhóis. Assim sendo, essa metade do século caracteriza-se, de modo igual, pela sobrevivência de um clima de guerra que acompanhava, no Sul, a economia da pecuária.

A pleno vapor, na época em que viveram os Gonçalves, também se estava completando a conquista de um território que, principalmente a partir do setecentos, deve-se a um processo de ocupação fundado, em última instância, em migrações internas muito peculiares. De modo geral, esse processo foi realizado a partir da costa, abrindo-se "por dentro" para o norte, para o oeste e para o sul. Caracteristicamente móvel, como foi visto, a população colonial tem como "motor" as atividades primário-exportadoras. Essa história é bem conhecida, compreendendo o pau-brasil, o açú- 
car, a mineração, a pecuária, uma indústria do couro, o café, a borracha e outros produtos da floresta. Entretanto, parcela importante da população estava voltada, muito mais, às lides cotidianas da sobrevivência e às possibilidades da posse da terra, sempre mais para o interior.

Está aí, dessa forma, embutido um regime demográfico que tem como uma das suas variáveis o povoamento; ou, talvez melhor, o povoamento articulado à criação de identidades regionais. Os sujeitos dessa história, componentes da população que se espalhou por todo um território que constitui, hoje, o país, são aqueles homens duros e determinados a encontrar no interior rude e perigoso o objetivo de sua vida - seja dizimando os indígenas que encontravam, seja aprisionando os que restavam, seja procurando ouro e pedras preciosas, levando o gado, buscando drogas nas florestas, seja, simplesmente, fazendo tudo isso e sumindo, haja vista a presença, entre os homens "livres" dos sertões, de desertores, escravos fugidos e outros marginalizados; seja, finalmente, se "estabelecendo". Assim, quando, em 1750, foi assinado o tratado de Madrid, as linhas que demarcavam as fronteiras entre os dois impérios coloniais americanos já eram, grosso modo, as mesmas de hoje, e "o critério que deu naquelas fronteiras tão atuais não foi senão o da ocupação". ${ }^{22}$

É muito provável que Gregório e Anna Maria, como boa parte dos seus vizinhos, desconhecessem tudo isso. Ao esboçar pela primeira vez a história dessa família, sugeriu-se que o marido tivesse a mesma condição social de sua mulher, ${ }^{23}$ mulata e forra, claramente expressa na ata do casamento. Porém, tendo em vista as atividades de mineração que iniciaram o povoamento da região de Curitiba e, antes, no litoral parnanguara, é possível que o marido descendesse dos primeiros faiscadores paulistas e vicentinos e que, à cata de ouro, passaram ou se quedaram por ali. Ou, talvez, fosse o fruto mais distante de uma relação rápida entre um mameluco e uma indígena - pois, além dos que buscavam fortuna maravilhados pela miragem dos metais preciosos, outros faziam guerra aos aborígines. Com efeito, a descrição física que se fez de Gregório corresponderia muito bem a esse tipo de mestiçagem. ${ }^{24}$ Nessa direção, Boxer refere-se aos

filhos destas uniōes ilícitas e temporárias (que), se chegavam à idade adulta, iam aumentar ainda mais o já extenso proletariado nômade, a plebe ínfima da sociedade brasileira, conforme a chamavam os cronistas coevos. ${ }^{25}$ 
Mas Gregório podia ser, finalmente, herdeiro de bandeirantes e "colonos". A abundância de espaços livres para povoamento, como no caso do sertão de Curitiba, bem como outros estímulos, levou, para citar um exemplo, o bandeirante Antonio Correia Pinto, o fundador de Lages, a dar "colocação ao sobreexcesso de agregados e mestiços livres". ${ }^{26}$ De qualquer forma, bandeirantes e colonos: aqueles haviam aberto e fizeram conhecer os caminhos pelo interior; estes seguiram sua trilha, aproveitando a profusão de terras que se encontrava sempre mais além, para o sertão. Para uns e para outros, uma atividade desenvolvida num quadro cultural muito peculiar.

Está se referindo, em especial, à região meridional, onde vivia Gregório e Anna Maria, e ao distante Norte, ambas fronteiras pobres, com

poucos homens brancos, menor quantidade ainda de mulheres brancas, pouca riqueza e dificilmente algum escravo negro [pelo menos, até meados do século XVIII]. As Instituições de Portugal foram reproduzidas nessas regiōes, mas assumiram uma forma atenuada. Cultural e etnicamente, ambas as regiôes eram acentuadamente indígenas na sua natureza. Desenvolveu-se no local uma população mestiça relativamente grande e [...] a exploração dos recursos do sertão e da população indígena tornou-se um meio de vida. ${ }^{27}$

Era, portanto, uma população que constituía parte de uma "cultura mestiça” e bastarda que preponderava no Sul e no Norte das possessóes portuguesas na América, e que ainda tinha como características, nas falas dos meios populares, sobrevivências da língua tupi.

Fosse como fosse, todas as categorias nominadas - forros, mestiços, camponeses pobres, agregados, peões e condutores de tropas, garimpeiros, mascates, pequenos artesãos, e outros - constituíam fração ou conjunto de uma população de pessoas mais ou menos desvalidas e que crescia com o desenvolvimento da colônia: geralmente, lá onde as regiôes eram mais povoadas, eram vistas como um problema para as autoridades..$^{28} \mathrm{Se}$ a sociedade colonial estruturava-se em torno do "eixo senhor-escravo", estes grupos constituíam parte importante das suas camadas intermédias. Evidentemente, outros agrupamentos também conviviam mais ou menos à margem do mencionado "eixo", mas numa situação superior. Refiro-me, por exemplo, aos clérigos, militares, comerciantes, pequenos proprietários e plantadores de açúcar, cuja riqueza somava-se em torno das poucas peças 
de escravos que possuíam. Entre esses, naturalmente, contava-se grande número de imigrantes portugueses, ${ }^{29}$ que detinham um grande trunfo em relação à massa da população: eram brancos, patrimônio facilmente negociável na sociedade de cor (ou sociedade de cores?) que se instaurou na colônia.

Mas os Gonçalves e a maioria dos seus vizinhos eram "gente pobre", parcela daquela camada social que não possuía escravos; formavam parte, também, dos "bastardos" de uma sociedade hierarquizada que privilegiava a identidade fundada em nobres cepas. Eram "bastardos" porque essa era, finalmente, sua qualidade, baseada na "ilegitimidade" racial e, portanto, social. ${ }^{30}$ Conviviam, no Sul, em grupos de população proporcionalmente rala e dispersa. Pela sua relativa desclassificação social, subsistiam muito próximos das populações cativas constituídas por ameríndios "administrados" e escravos de origem africana; duplamente próximos, porque, muitas vezes, dedicavam-se às tarefas menos nobres que a especialização do sistema não permitia aos escravos se dedicar.

É muito provável que as condiçôes de vida da família fossem guiadas pela prudência. Prudente foi, nesses termos, a decisão de Gregório e Anna Maria em formalizarem o matrimônio, ela, com 19 anos e ele, com 23. ${ }^{31}$ Os jovens pertenciam a um grupo relativamente estável de pessoas que tinham sua vida regrada, em princípio, por uma agricultura de subsistência. Eram núcleos que se constituíam nos "bairros", cuja base territorial e padrão comunitário levavam seus componentes a exprimirem um sentimento de localidade. Geralmente, era formado por uma "porção de território subordinado a uma povoação, onde se encontram grupos de casas afastadas do núcleo do povoado, e umas das outras, em distâncias variáveis". ${ }^{32}$ Eram os "bairros -, onde a adaptação ecológica, a vida econômica, a cultura e a organização social integraram-se em termos mínimos vitais, mas de modo a permitir seu funcionamento econômico". ${ }^{33}$

Muito embora o modelo destes bairros tivesse sido estabelecido a partir da experiência "paulista", ${ }^{4}$ é possível se perguntar se ensaios semelhantes não tivessem se generalizado na colônia, organizados à medida que avançava, para o interior e para o sul, a linha de relativa estabilidade familiar que se caracterizava a partir das zonas mais tradicionais do litoral; isso era verdade para os aglomerados urbanos e, também, para as zonas de lavoura 
para exportação. Quanto mais se alçava a vista para o sertão, as pessoas que por lá perambulavam e, eventualmente, fixavam um local de moradia, tinham como marca a mobilidade do domicílio e, de forma parecida, muitas "cazas" chefiadas por mulheres. As regiōes de mineração, pelo menos nas suas fases iniciais, eram percorridas por garimpeiros que mal acampavam para logo seguir adiante - mas, às vezes, deixavam atrás de si, arremedos de povoados. Assim se originou o povoamento do litoral sul das possessóes portuguesas a leste de Tordesilhas e, depois, o planalto serra acima. Da mesma forma, a ocupação norteada pela instabilidade demográfica e social resultante da descoberta do ouro nas Minas Gerais, em Goiás e Mato Grosso. Foi assim também, ou mais ainda, quando "bandeiras de guerra" avançavam pelo interior, buscando o espólio indígena. $\mathrm{E}$, de modo muito parecido, na ocupação da região mineira de Apiaí, na Capitania de São Paulo. Em 1732, portanto muitos anos antes de Gregório e Anna Maria terem nascido, informações indicam que, para cada 100 domicílios constituídos, 64 eram ocupados por uma só pessoa; destas, 53 eram homens e 11, mulheres. A maioria dos fogos ${ }^{35}$ restantes (34\%) era organizada por casais, com ou sem filhos. É muito provável que a precariedade dos domicílios resultasse da própria condição do estilo de vida do garimpo. Alicerçava-se em uma atividade penosa e desgastante e, ainda mais, de poucos lucros, que requeria a mobilidade do faiscador, sempre atrás de novas áreas a serem pesquisadas: "os homens abandonavam com freqüência (as) mulheres, com a mesma facilidade com que deixavam suas habitaçôes improvisadas ao ouvir boatos de descobertas de ouro em outros pontos dos matagais." ${ }^{36} \mathrm{O}$ que também explica, nas Minas Gerais, o elevado número de domicílios chefiados por pessoas do sexo feminino, geralmente mestiças. Porque também faz parte desse quadro - e isso é tanto mais verdade quanto mais se avança para regiões remotas - o elevado índice de miscigenação, fundado na quase inexistência nessas regiōes de mulheres brancas.

Em Apiaí, a situação mudou bastante, no início da segunda metade do século XVIII. Um recenseamento realizado em 1765 possibilitou contabilizar quase $56 \%$ de domicílios habitados simplesmente por casais com ou sem filhos, contra aqueles 34\%, já mencionados, no censo anterior. As casas ocupadas nesse ano por pessoas sozinhas somavam praticamente $40 \%$ ( $24 \%$ a menos do que na contagem mais antiga). Mas o ouro 
já havia diminuído, dando lugar a uma economia que se traduzia, em termos socioeconômicos, na fixação da população.

Os números se inverteram: qual o significado desses dados? " $A$ importância assumida pelos domicílios simples ao longo do tempo reflete o enraizamento populacional na região e os vínculos firmados na localidade, aqui medidos através da formação de famílias" ${ }^{37}$ Ora, tudo indica que o que ocorreu mais ao norte já havia ocorrido antes no planalto curitibano. Ainda se teimava em encontrar betas de ouro, na época em que ali viveram Gregório e Anna Maria. Entretanto, quase na mesma época em que se fez a segunda medição na vila de Apiaí, em 1776, eles e outros constituíam unidades populacionais de caráter diverso, predominando os fogos relativamente estáveis. ${ }^{38}$ Entre os 434 domicílios, só 10 eram, seguramente, choupanas constituídas de solteiros solitários, desenraizados e vivendo ao deus-dará. Em 1785 a proporção diminuiu ainda mais, oito fogos num total de 595; ou seja, passou de 2,3\% do total para 1,3\%. ${ }^{39}$ Talvez se constituísse signo ainda maior da estabilidade das comunidades que organizavam a população do planalto curitibano o fato de, nos nove anos que separam os dois recenseamentos acima mencionados, os domicílios mais complexos (extensos e múltiplos) terem crescido de $4,4 \%$ para $16,6 \% .{ }^{40}$

Portanto, desde quando se iniciou, no final do século XVI, a atividade de garimpagem no território que hoje faz parte do Paraná, a mobilidade concernente estava apoiada na fartura da mão-de-obra indígena destinada ao transporte da equipagem e do produto da colheita dos mineradores $-\mathrm{o}$ ponto de partida e de chegada destes nômades era São Paulo. Mas o indígena, preado para exercer um trabalho mais rentável no litoral paulista, rapidamente desapareceu do litoral. E, logo, da chapada curitibana. Tudo isso, mais a incômoda distância do ir-e-vir dos mineradores, levou gradativamente à organização de arraiais nas costas e serra acima. Do ponto de vista da estabilidade familiar, é possível aventar que o desaparecimento do indígena enquanto mão-de-obra é consistente com as dificuldades cada vez maiores da "posse" temporária de mulheres aborígines.

De modo que, resumindo, a estabilidade da família e do domicílio desenvolve-se concomitantemente - e em conseqüência - à decadência das atividades de garimpagem nômade e a mudanças de estratégias de sustento; mas, também, era função indireta do gradativo interesse das autorida- 
des do Rio de Janeiro em relação a Paranaguá e Guaratuba. Isso, para o litoral. No planalto, o lento "estabelecimento" da população resultava da gradativa especialização de uma economia fundada na pecuária e no comércio de tropas, sustentada por uma agricultura de subsistência. De fato, esse novo gênero de vida "foi exigindo esforços sedentários, fixados em torno dos 'currais' da criação e foram surgindo os sitios e nas zonas deles os arraiais estáveis, nebulosas de aldeias, vilas e cidades." 41

Eram as atividades econômicas geradas pelo grande desenvolvimento da exploração do ouro e diamante no Centro-oeste da colônia, durante o século XVIII, que constituíram a mola propulsora dessa orientação. Normalmente, fixam-se como a grande região afetada pelas atividades mineiras partes dos atuais estados de Minas, Goiás, Mato Grosso, e parcela da Bahia, abrangendo uma área que poderia alcançar dois milhões de quilômetros quadrados. Se incorporarmos o interior de São Paulo e Paraná, por volta da passagem do século XVIII para o XIX, teríamos envolvido por esse tipo de povoamento - direta ou indiretamente - cerca de 800 mil pessoas. ${ }^{42}$ Uma parte delas desenvolveu uma "cultura do nomadismo", que deve ser considerada seriamente ao se levantar o tema da dinâmica populacional que caracterizava a sociedade colonial brasileira.

De certo modo acompanhando os deslocamentos iniciados pelo bandeirantismo, essas atividades eram alicerçadas por um determinado tipo de agricultura de subsistência. Sua peculiaridade era a itinerância, da mesma forma que era itinerante a mineração; fundava-se em técnicas rudimentares, seguindo a própria mobilidade da população, que vivia ao mesmo tempo das atividades de coleta, pesca e caça. Se alargada esta perspectiva para todo o interior da colônia (incluindo-se as outras regiôes de criação que se expandiram a partir da Bahia e do Nordeste - além da Amazônia portuguesa) e, mesmo, para partes das regiōes litorâneas, a idéia da aventura que se esvai para dar lugar ao "estabelecimento" permitiria imaginar a instalação de um regime demográfico característico - à medida, como foi dito antes, que pessoas se estabelecem, em número relativamente significativo, sob o signo de um domicílio simples e ou mais complexo.

Trata-se, naturalmente, de um regime diferenciado em relação àquele de uma economia de plantation, que se implanta no Nordeste e de modo gradativo caminhava para o Sudeste; diferente, da mesma forma, dos aglo- 
merados urbanos, localizados mais próximos à costa, com características próprias - e, da mesma forma, das vilas que proliferaram em torno e em função da expansão das minas, nas Gerais e em Goiás. ${ }^{43}$

Portanto, os bairros antes referidos estavam marcados por uma "unidade frouxa, que poderíamos denominar centrífugos, propiciando um minimo de interação". Todavia, à medida que parte dos lares firmava-se na idéia de que era possível criar excedentes para atender às demandas das fazendas de gado, verdadeiras autarcias na economia regional, constituía-se uma "vida social e cultural mais rica, favorecendo a convergência dos vizinhos em atividades comuns, num ritmo que permite chamá-los centripetos". ${ }^{44}$

$\mathrm{O}$ que havia de comum entre o domicílio dos Gonçalves e dos seus vizinhos, finalmente - por mais afastados que estivessem, coesos e suficientes em si mesmo - era a relação que tinham, ainda que esporadicamente, com o "centro provedor de sal, administração e ministério religioso" 45 , localizado na Vila de Curitiba. Nesse contexto, e ao longo de parte do século XIX, a freguesia curitibana constituiu-se em centro irradiador de uma população que se espraiava para o oeste; gradativamente se estabelecendo.

Prudente foi não só a formalização, mas, da mesma forma, o investimento do casal no casamento, que representava segurança e um ideal de respeitabilidade a ser atingido. ${ }^{46}$ Não era pouco comum, no meio em que viviam, os amancebamentos. As dificuldades burocráticas colocadas pela Igreja e os emolumentos cobrados dificultavam a formalização da união sobretudo àquelas pessoas que vieram de longe, deixando também longe os testemunhos e as provas de que não estavam impedidos de casar. Essa situação, provavelmente, combinava-se com hábitos herdados dos primeiros tempos da colonização, relacionados a práticas matrimoniais trazidas pelos portugueses da Metrópole muitas vezes pressupondo apenas uma coabitação prolongada. ${ }^{47}$ Com o tempo, evidenciava-se uma espécie de "banalização" da união consensual, relevada pela sociedade. Em outros termos, no quadro lógico dos séculos XVI e XVII na colônia - e, é muito provável, também no XVIII - "na mesma medida em que tudo era pecado, quase nada era objeto de escândalo e indignação". ${ }^{48} \mathrm{Na}$ base de tudo estavam as formas culturais características de uma sociedade que se constituía articulada a um processo de ocupação e colonização de imenso território. Essas práticas não se coadunavam com as exigências de legitimação das 
uniōes, sempre muito explícitas, por parte da Igreja. Com efeito, a contradição em parte se explicava pela flexibilidade do "baixo clero" na aplicação das normas conciliares e pela resistência que opunham às tentativas dos bispos, para determinados casos, em tornar gratuito o casamento para os pobres. ${ }^{49}$ Os modestos curas das paróquias mais distantes não tinham nem interesse nem clarividência para contribuir com seu esforço para a legalização dos diversos tipos de mancebias que vigoravam na colônia.

Considerando o conjunto de curitibanos, cujas núpcias foram oficiadas pelo sacerdotes católico, na segunda metade do século XVIII (média do casamento era de 21,2 para as moças, e 26,8 para os rapazes), ${ }^{50}$ Gregório e Anna Maria teriam se unido de forma um um tanto mais precoce como informei acima, ele com 23 anos, ela com 20. Todavia, os testemunhos da época mostram que era bastante importante, por exemplo, o número de adolescentes que se casavam a partir dos 14, 15 (e, mesmo, dos 13) anos de idade; era, pois, bastante estendida a distribuição total das idades do início da vida matrimonial. Não se lhes colocava a necessidade de acumular um cabedal inicial para poderem casar. Todo o planejamento que devem ter feito fundamentou-se na edificação de uma casa em uma posse de terra, da qual pudessem tirar seu sustento e criar os filhos que lhes daria a Providência.

É evidente que, no que concerne às "médias" acima verificadas, a tendência de um casamento tardio para o conjunto dos homens precisa ser mais bem ponderada em função do estudo da distribuição das idades. Como mostra Bacellar, as médias obtidas para o casamento dos homens em Curitiba (26,8 anos) diferem somente de um ano, na comparação com aquelas em que alguns proprietários de engenhos se casaram, no Oeste paulista (27,7 anos). Realmente, esses números seriam bastante consistentes com os comportamentos esperados para a elite branca. Em relação às mulheres, a pequena diferença apontada (21,2 para as noivas curitibanas, 19 anos para as filhas dos proprietários paulistas) deve ser avaliada tendo em vista, da mesma forma, a distribuição. Ao contrário das moças da Paróquia de Nossa Senhora da Luz dos Pinhais, praticamente se contam poucas nubentes adolescentes entre as herdeiras dos senhores de engenhos de açúcar. De qualquer modo, para as famílias da elite branca, o constrangimento das questões relacionadas ao patrimônio era importante. Assim, por 
exemplo, para estas camadas do topo da estrutura social as unióes consensuais não eram prática corrente ${ }^{51}$ eram, mesmo, impensáveis, dada a relação entre a herança e a legitimidade da geração dos filhos.

É importante frisar que as elites - cujo protótipo estava organizado no Nordeste, em torno dos engenhos -, tradicionalmente ligadas às atividades mais nobres de administrar grandes propriedades agrárias, absorveram com êxito aquelas camadas que enriqueceram a partir de outros meios, como o comércio e as atividades nas minas. As antigas famílias sempre tiveram a tendência de consolidar alianças entre si pelo casamento; porém, eliminados pragmaticamente os preconceitos, foram firmando alianças matrimoniais até com comerciantes enriquecidos, além das filhas, naturalmente, que eram dadas a descendentes de famílias com nome e prestígio nos quadros políticos do Império. Este pragmatismo - que se articulava ao ajustamento das grandes famílias coloniais a um Estado mais ativo e intervencionista, como o que se desenvolve a partir de Pombal - somente teve êxito, é necessário lembrar, em função da base institucional da escravidão e em suas concomitantes distinçôes sociais. ${ }^{52}$

A prudência necessária e desejada também estava relacionada à violência típica da sociedade colonial. Junto com os "facinorosos do sertão", não era incomum que Gregório ou um dos seus filhos se deparassem, vez ou outra, com escravos fugidos ou indígenas desgarrados e belicosos, os poucos que ainda restavam após a conquista e colonização da região. Em toda a capitania, como aliás em toda a colônia, foi constante a atividade dos bandeirantes mamelucos, enquanto existiam indígenas cuja preagem e trabalho fossem rentáveis. Dessas ações, resultou o desaparecimento dos carijós; primeiramente, do litoral. Logo, os paulistas seguiram estes indígenas no planalto curitibano. "Pacificados" estes aborígines, os bandeirantes voltaram-se, cada vez mais, às reduçôes espanholas. Iam cada vez adiante, mais para o interior, a oeste e ao sul, utilizando-se dos caminhos pré-colombianos do Peabiru. Conhecemos o final dessa triste história: o resultado foi a destruição das reduções e fuga dos jesuítas e parte dos indígenas para o sul, transformando-se a região ocidental do atual Estado do Paraná numa vasta terra de ninguém, cujo "vazio" - reocupado pelos caigangs e botocudos ${ }^{53}$ - ficou à margem da colonização pelo menos por um século e meio. Ou seja, desde o sucesso da expedição organizada em 1628 por 
Manoel Preto e Raposo Tavares até o início da segunda metade do século XVIII quando, é preciso lembrar, constituiu família em Curitiba Gregório Gonçalves.

Histórias semelhantes ocorreram em toda a colônia. Os indígenas, que as estimativas muito díspares projetam entre 1 milhão e quase 2,5 milhões quando da "descoberta" do Brasil, ${ }^{54}$ desapareceram rapidamente do litoral. Primeiro, em função da guerra de extermínio e da escravização, aliado ao processo de "desculturação" encabeçado pelos jesuítas. ${ }^{55}$ A imposição de um "excesso de trabalho, e moléstias, eram aumentadas pelas baixas infringidas às tribos que resistiam à domesticação, ou que por qualquer outro motivo incorriam na cólera do branco" ${ }^{56}$ Por um lado, o ameríndio tornouse redundante - pelo menos até que Pombal o tivesse parcialmente reabilitado $^{57}$ - e essa situação foi particularmente evidente nas regiōes dominadas pelo avanço da pecuária: ali, e em especial nas capitanias do Norte e Nordeste (mas até, também, nos Campos dos Goitacases, no Rio de Janeiro), desenvolveu-se um clima de guerra na relação com os indígenas. Por outro lado, estes nativos não estavam protegidos biologicamente contra as doenças trazidas pelos europeus. Particularmente vulneráveis à varíola, o contato com o conquistador gerou uma grande mortalidade também em função de doenças como sarampo, sífilis, tuberculose, tétano, lepra, infecções pulmonares e intestinais; enfim, de febres diversas. ${ }^{58}$ No censo de 1798 , contabilizaram-se 252 mil índios "pacificados" (7,8\% da totalidade da população da colônia). "Quando em 1819 foram contados todos os indios, inclusive aqueles ainda não subjugados, a população nativa foi estimada em cerca de 800 mil almas, um terço do que fora em 1500 e 18,2 por cento da população total do Brasil'. 59

Além das razões apontadas, a violência imperava por se tratar de uma região de fronteira. Tudo levava, portanto, a uma população "militarizada" ${ }^{60}$ Cada indivíduo, em especial os solteiros, era passível de ser convocado para prestar serviço. Tal preferência poderia naturalmente livrar Gregório. Os seus filhos varões (Felizberto, Bento José e Felizardo) escaparam da possibilidade de qualquer arregimentação, por serem muito jovens ${ }^{61}$ - pelo menos, no período coberto por esta história familiar. De qualquer forma, sobre eles e os vizinhos, em tempo de guerra imperava a organização rígida do sistema das milícias, tendo à testa capitães-mores, que havia sido encar- 
regado de efetuar o censo da população. Deveria arregimentar "todos os moradores que se achassem no estado de servirerm nos terços e auxiliares, sem excepção de nobres, plebêos, brancos, mestiços"; ${ }^{62}$ e armados à sua própria custa. $\mathrm{Na}$ Capitania de São Paulo, mais do que em outras regiōes, a organização das listas tinha essa feição. O domínio da Vila de Curitiba, por exemplo, era dividido no século XVIII em cinco companhias de ordenança, abrangendo um amplo território da Quinta Comarca. A população era contabilizada por fogos, em função das referidas companhias de ordenanças. Essas eram divididas em bairros, abrangendo habitantes não só do "rocio" da vila, mas também de localidades e povoações dispersas; inclusive, das fazendas.

Em diversos momentos da segunda metade do século XVIII, como evidencia a tabela 1 (anexo), os membros do domicílio dos Gonçalves foram arrolados. Em especial, a lista de 1797 registra uma família de portentosa fecundidade, fruto em parte do fato de terem começado cedo a vida reprodutiva e, é evidente, de a esposa ter sobrevivido aos sucessivos partos. O casal teve nove filhos, como foi mencionado: Felizberto, Bento, Maria, José, Rosa, Maria (novamente), Izabel, Felizardo e Anna. A recuperação destas e de outras informaçóes relativamente ao casal durante o desenrolar da segunda metade do século XVIII - a partir do batismo de Anna Maria em São José dos Pinhais, até a morte de Gregório, já no século XIX - denota um domicílio relativamente estável, tanto do ponto de vista social como demográfico. Mas também - é muito provável - tratava-se de uma família cujos componentes mais jovens nada deviam ao serviço de Sua Majestade. ${ }^{63}$

Essa estabilidade contrasta com a instabilidade (e mobilidade) que regia boa parte da vida de parcelas importantes das camadas "intermédias" da população colonial. O nomadismo (ou seminomadismo, como é definida a população "caipira” paulista ${ }^{64}$ ) característico dos componentes desses grupos "impedia que se estabelecessem entre eles relaçôes dotadas de durabilidade necessária para a cristalização de obrigaçôes tradicionalmente aceitas",;5 inclusive, de obrigações "familiares". Seu nomadismo ajustava-se, bem como sua vida em geral, ao meio. Muitas vezes, à mobilidade maior masculina: como foi antes mencionado, para o homem, em especial, havia sempre a possibilidade de "sair de casa", de buscar recursos ou riquezas mais além, abandonando o domicílio. É nesse quadro, articulado a uma contextura da "ilegitimidade", que se explica o grande número de fogos dirigidos pelo 
por mulheres, de modo igual mestiças: na Vila Rica, por exemplo, por volta de $1740,45 \%$ de todos os domićlíios arrolados eram dirigidos pelo elemento feminino. ${ }^{66}$ Filhos de relações não sancionadas pela Igreja, ou parte dos enjeitados, estes bastardos e desclassificados estavam sempre prontos a produzir crianças ilegítimas por onde passavam, o que poderia se dar exatamente com uma mulher abandonada.

Enfim, esta mobilidade combinava-se com a instabilidade gerada pelas flutuações do mercado nos engenhos de açúcar, lá nas regiōes gradativamente anexadas àquelas onde tudo começou. Da mesma forma, com a atividade nômade e predatória das bandeiras, muitas vezes descritas por verdadeiros latifúndios em marcha. De modo igual, com a convivência de um sistema de escravidão que, mesmo importando braços cativos da África, não poupava a população ameríndia. Era uma mobilidade que estava ligada à ética muito própria e original, com a "posse" da terra, das riquezas e das mulheres indígenas - sem mencionar as africanas -, a uma moral particular desenvolvida na contradição entre os preceitos da Igreja e as necessidades cotidianas e de sobrevivência do "colonizador". Ajustava essas características um temperamento próprio, no qual predominava a "aventura", ${ }^{67}$ articulado à mestiçagem racial e cultural.

Porém, ao contrário, a fixidez da família constituída pelos atores principais em Curitiba incluía a união matrimonial abençoada pela Igreja. $\mathrm{Ou}$ seja: é possível inferir que o casamento, naquela época, era mais acessível às pessoas de poucos recursos num quadro de estabilidade. Para os pretendentes oriundos de paróquias mais distantes, os custos e as dificuldades para atender às imposições burocráticas da Igreja, como já foi mencionado, chegavam, muitas vezes, a obstar a união legal. Portanto, se, por um lado, Anna Maria nasceu na região - os registros paroquiais o comprovam -, ${ }^{68}$ sabe-se que Gregório teria subido a serra com sua família, provavelmente muitos anos antes; ${ }^{69}$ tudo isso reforça a idéia de um grupo familiar relativamente consolidado nos campos curitibanos antes de 1772, quando se realizaram as núpcias.

Da mesma forma, era uma família estável, porque suas crianças puderam ser recuperadas pelos batismos realizados numa só paróquia - inclusive, alguns (assim ficou provado pela documentação - ver tabela 1, anexa) casaram-se e morreram na própria freguesia. Crianças essas (sem contar 
possíveis abortos) que se seguiram num padrão demográfico clássico de populaçóes pré-malthusianas. Ainda - e aqui refere-se em especial aos cônjuges - porque tiveram, ambos, uma vida longeva, extraordinária em função do clima de morbidade e mortalidade que caracterizava as sociedades tradicionais do passado. Estável, porque localizados na mesma Segunda Companhia de Ordenança, não obstante terem sido encontrados em cinco pequenas comunidades diferentes, em momentos diversos dos recenseamentos realizados em Curitiba. ${ }^{70}$

Apesar das conclusões gerais, as implicações relacionadas à mudança de um local a outro, dentro da própria regiáo, poderia aventar melhoria de situação - no mínimo, sempre seria necessário abandonar uma "casa" e construir nova, abandonar um "sítio" para se assenhorear ou negociar outro.

Finalmente, uma estabilidade econômica e social - quase uma constatação redundante para o grupo social ao qual pertenciam -, porque se mantiveram pobres. Embora as atividades na região pudessem amealhar fortuna para alguns, as informações que se têm permitem afirmar que nunca conseguiram possuir escravos, e a posse de um cativo, em idade produtiva, já era um diferenciador de riqueza. ${ }^{71} \mathrm{E}$, para completar e finalizar, eram um grupo familiar estável mas de vida medíocre, o que não autoriza incluí-los no limite extremo da pobreza. A Câmara de Curitiba pinta um quadro no qual é possível, facilmente, incluir a família Gonçalves:

Os moradores da freguesia desta vila (de Curitiba), além de não serem as terras muito frutíferas, e porque não tem para que nem para onde dêm consumo ao fruto de suas lavouras, estão já no costume de plantarem tão sòmente quanto baste para o sustento de suas famílias, porque sempre o que lhe sobre o perdem do bicho, e se o aproveitam é só emprestando aos vizinhos que precisam, para o tornarem quando o tem, por este motivo já estão em hábito de não fazerem esforço em grandes plantações, porque nunca alcançaram disso utilidade. ${ }^{72}$

É evidente que o "estabelecimento" da família estava relacionado às próprias possibilidades de sobrevivência dos seus membros. Deviam ter ou viviam de - um pequeno sítio, obtido ou pela posse, ou em função de um contrato de obrigações com seu proprietário. Além da mandioca obtida do litoral, viviam principalmente do milho e do feijão, plantados por 
eles e, tendo em vista as especificidades da região, a família, sazonalmente, dedicava-se à colheita da congonha (erva-mate). ${ }^{73}$ É provável que, influenciados por costumes indígenas, complementassem, vez ou outra, e na época apropriada, a dieta alimentar com o pinhão da araucária. Criavam galinhas e pequenos animais e, por que não, talvez alguns novilhos, originados do desgarre de alguma manada que passasse pela região. É plausível, ainda, que, como outros, complementassem o sustento com a caça ${ }^{74}$ e vivessem de certos expedientes: no cenário de uma sociedade pastoril como aquela que se descreve para o sul e para o interior da colônia, ainda que relativamente vigiada pelas autoridades metropolitanas, era comum o roubo do gado e o contrabando. É possível ainda imaginar que Anna Maria pudesse exercer pequenas atividades ligadas ao comércio varejista ambulante, como era comum na colônia, entre mulheres descendentes de africanas, escravas ou livres. ${ }^{75}$ Todas essas possibilidades, que não deveriam naturalmente enriquecer ninguém, poderiam também explicar o "entusiasmo" do casal em gerar um filho atrás do outro, cuidando deles de maneira adequada: as crianças, ao que tudo indica, chegaram à idade em que puderam contribuir com sua parte na produção doméstica. ${ }^{76}$

Vez ou outra, Gregório fornecia seus serviços em fazendas de criação ou invernada de gado, ou em pousos, como havia muitos na região. É verdade que a demanda por força de trabalho externa à estância, naquele contexto, era bastante difícil, dadas as características do artesanato e do trabalho escravo que se desenvolveu naquele sistema: sobravam poucas atividades específicas ao homem livre. ${ }^{77}$

Seja como for, os múltiplos labores exercidos pelo casal e seus filhos constituíam oportunidades para, em especial, Gregório e sua mulher, terem contato continuado com componentes das milícias, pois os postos militares espalhados no sul da colônia estavam dispostos geograficamente numa certa freqüência. Em torno deles desenvolveram-se pequenos povoados, bem como nos locais de travessia dos rios, onde se organizavam - como no Rio Negro (fronteira sul da capitania de São Paulo) - postos de registros para controlar a travessia "dos gados e cavalgaduras". Portanto, embora fossem comum os encontros de Gregório, em suas andanças, com tropeiros $^{78}$ albergados em ranchos espalhados pela região - também fontes de pequenas aglomeraçóes populacionais -, ele não quis ou não pôde 
desenvolver nenhum trabalho relacionado a este tipo de atividade. Essa certeza comprova-se pela mobilidade característica dos condutores de tropas. Sobre essa categoria, é possível imaginar que o contato desses com suas mulheres era parcialmente interrompido pelas longas viagens em que iam buscar mulas e bois nos campos do Viamão para serem levados a Sorocaba: tal fato deveria, sem dúvida, num regime demográfico muito particular, condicionar a fecundidade desses casais. ${ }^{79}$

\section{Um regime demográfico de alta natalidade e alta mortalidade}

A tendência em se sintetizar desta forma a demografia do passado colonial brasileiro tende a minimizar a complexidade inerente ao processo histórico. Nas duas sessões anteriores, foi salientado como a sua problemática tem como componentes a dinâmica mobilidade versus estabilidade e, de modo articulado, as migraçóes de povoamento. Seguem-se, agora, algumas considerações a respeito de, na mesma complexidade, ainda aventar as possibilidades de outros sistemas e ou regimes demográficos restritos.

A história de Gregório e Anna Maria é, portanto, resgatada. Primeiramente, dir-se-ia que, pelo menos em um aspecto, a vida do casal e seus filhos foi afetada pelas medidas, até certo ponto revolucionárias, de Pombal. Estão em destaque, nesse sentido, as estratégias político-administrativas adotadas pela Metrópole, no bojo das quais inseriam-se aquelas relacionadas ao controle da população, que as autoridades tentavam implementar com a contagem nominal e anual dos habitantes da capitania. Até que ponto este clima interferiu nos comportamentos reprodutivos do casal, é difícil especular. Entretanto, é provável que, de uma maneira ou de outra, os grupos sociais da região foram afetados.

Por outro lado, é possível supor que a fecundidade do casal e de outras pessoas da comunidade estivesse relacionada às tradições patriarcais que eram típicas das camadas mais altas mas que, não obstante, influenciaram, em várias características, as famílias dos estratos livres e sem posses. Se valem as generalizações, é possível aventar adiante: os comportamentos reprodutivos radicavam-se na maneira com que as pessoas comuns organizavam-se em determinada região. Assim, é possível imaginar o bairro como 
tendo sido iniciado pelo casal Gonçalves e alguns vizinhos, ao ocuparem de algum modo a terra e estabelecendo as bases da sua exploração e povoamento. ${ }^{80}$ Ao mesmo tempo crescendo, com a fixação de domicílios constituídos por seus filhos, genros e noras, ${ }^{81}$ de modo que, a uma relativa estabilidade do domicílio e ao fundamento territorial, juntava-se o vínculo da solidariedade de parentesco. Na direção, portanto - deve-se insistir da comunidade, quando essas relaçôes ultrapassam as próprias relações de sangue, mantendo, no entanto, as articulações interpessoais como se fossem entre parentes, fortalecendo a unidade e "desenvolvendo sua consciência própria". ${ }^{82}$

É fácil constatar, como já foi comentado, como a união dos Gonçalves foi fecunda. Com efeito, mesmo nas camadas mais pobres da população, ou em regiões rurais, é difícil hoje em dia encontrar muitas mulheres tão prolíferas quanto Anna Maria, naqueles idos do final do século XVIII. Nove filhos paridos, praticamente de dois em dois anos, entre 22 e 40 anos de idade: quando nasceu Anna, a ultimogênita, sua mãe estava bem próxima da idade limite da fertilidade (convencionalmente, 45 anos nas populaçōes antigas).

Mesmo para a época, comparada à média de quase oito filhos nascidos por casal em Curitiba na segunda metade do século XVIII, entre a população livre, a fecundidade do casal foi alta. Realmente, os intervalos médios entre os nascimentos da grande maioria das crianças curitibanas, observadas em mulheres que na época alcançaram os anos-limite mencionados, antes do fim da união, eram maiores do que os intervalos sucessivos constatados para a família Gonçalves. Além disso, a idade de Anna Maria, ao dar a luz seu último filho - em torno dos 41 anos -, permite constatar que esta história materna não destoava de um comportamento médio das curitibanas em geral (40,6 anos de idade na última parturição, para as mulheres cujas histórias matrimoniais desenvolveram-se na segunda metade do século XVIII). Em suma, a idade de Anna Maria quando casou, caracterizando de um lado casamento relativamente precoce e, de outro, os espaços sucessivos entre os nascimento de seus filhos e a idade da última maternidade relativamente tardia, não contrariava a tendência geral encontrada para os casais mais estáveis da comunidade curitibana, naquela época. ${ }^{83}$ 
Cabe, por outro lado, indagar até que ponto a realidade demográfica paranaense no século XVIII, no que concerne à natalidade e à fecundidade, era diferente da situação brasileira em geral. Embora não baste uma constatação a mais para comprovar uma hipótese, é útil de qualquer modo referir-se ao fato de que o tamanho médio da família de caiçaras no litoral mais ao norte de São Paulo, na primeira metade do século XIX, não se distanciava, de modo nenhum, do que ocorria no planalto curitibano. ${ }^{84}$

O complicador está em passar dessas noções vagas relativas à alta natalidade das populações ditas tradicionais para nuanças restritas, próprias de sociedades e grupos sociais diferenciados. Nesse sentido, já é possível, na atualidade, contrapor populaçóes diferentes. Por exemplo, as pesquisas antes referenciadas a respeito de Curitiba, na segunda metade do século XVIII, e Ubatuba, no limiar do XIX, fundadas nos métodos de reconstituições familiares, e em que pese as críticas que se fazem à metodologia, registram descendências finais extraordinariamente elevadas que, ao que tudo indica, somente eram ultrapassadas pela população do Canadá francês, na mesma época. Entretanto, é necessário ressaltar que a fecundidade das mulheres brasileiras iniciava-se, em média, muito mais precocemente do que das européias e canadenses, o que poderia explicar, basicamente, a maior descendência das brasileiras. Mesmo assim, os intervalos entre os nascimentos nas mães curitibanas tendiam a ser um pouco maiores do que aqueles calculados para as populações européias, igualmente "camponesas" e pré-malthusianas.

Considere-se, ainda, que a amamentação retarde durante algum tempo o reinício da ovulação na mulher. Contudo, mesmo amamentando, havia "espaço" para mais filhos na vida fecunda feminina no Brasil colonial, que podem não ter nascido em virtude de uma maior incidência de abortos. De modo geral, poderia ser colocada uma hipótese relacionada a este comportamento diferencial: estaria relacionada às disparidades dos modos de vida, clima e alimentação. ${ }^{85}$

Essas questôes todas foram postuladas, tendo em vista os comportamentos reprodutivos. Ora, é sabido que, no limite, os valores relacionados à vida humana estão articulados à visão que as pessoas têm da morte e do próprio sobrenatural. É também generalizado o senso comum: a vida, para as populações antigas, era muito curta. Todavia, Anna Maria viveu até cer- 
ca de 73 nos. ${ }^{86}$ Gregório, o que era ainda mais extraordinário, sobreviveu à sua mulher, falecendo com 95 anos - quase um ano depois da morte de seu segundo filho. ${ }^{87}$ Apesar do caráter inusitado destes exemplos, talvez espelhem esperanças de vida relativamente mais elevadas do que em outros regimes demográficos da colônia. Consequiência, é provável, de ausências maiores de crises epidêmicas (população mais rarefeita) e, no caso curitibano, de um ambiente climático mais favorável.

Assegurada a alimentação durante todo o ano, a sociedade brasileira tradicional praticamente não conhecera, como até há pouco ocorria na Europa, nem as crises de mortalidade, nem as crises de subsistência que, aos se superporem, causavam terríveis danos às comunidades locais. Eram as chamadas "mortalidades de crises". Dada a dispersão da população, praticamente evitavam-se os contágios e a propagação de doenças, como a varíola e, mais tarde, a febre amarela e o cólera-morbus, comuns onde havia relativa concentração de efetivos populacionais. A elevada e característica mortalidade resultava principalmente da incidência de doenças endêmicas, causadas por moléstias parasitárias e infecciosas de tipo tropical. Além disso, somava-se o desconhecimento completo de preceitos de higiene, o que contribuía para ceifar de maneira contínua parte substantiva das crianças, antes que completassem o primeiro aniversário (entre 190 e 214 por mil), e abreviando a vida dos adultos (esperança de vida ao nascer entre 30 e 40 anos). ${ }^{88}$ É evidente que Gregório, Anna e seus filhos burlaram essas tristes estatísticas.

Normalmente, naqueles tempos, a causa-mortis não era registrada na documentação, embora alguns vigários fizessem algumas anotações. $\mathrm{Na}$ paróquia curitibana, em certas atas, o padre observava: "faleceu subitamente". Também deparou-se, o que era consistente com o clima belicoso do século XVIII, com a menção "faleceu em seguida a ferimentos por arma de fogo" ou, mesmo, "faleceu em seguida à luta contra os indios". No que se relaciona às mulheres, foram encontradas esporadicamente informaçōes de que determinada pessoa morreu de parto, ou em seguida a uma hemorragia. Quando se inicia o século XIX, dependendo sempre do vigário de plantão, as informações a respeito da causa da morte melhoram, com referência às doenças que teriam levado ao óbito de determinado indivíduo. Conseqüentemente, são cada vez mais comuns, à medida que deixamos o 
século XVIII para trás, menções como: morreu de maligna, tísica, estupor, lombriga, lepra, bexiga, [...] "Entre as doenças comuns, que atacavam tanto brancos como pretos [...] estavam a disenteria bacilar, os vermes intestinais e as moléstias venéreas", ${ }^{89}$ que quase invariavelmente desembocavam na morte.

Esse cotidiano sofria distinções regionais, que eram coerentes com as variedades nos gêneros de vida. Já foi mencionado, por exemplo, a definição de uma economia regional marcada pela fazenda de criação de gado que ocupava, cada vez mais, o interior paranaense, no planalto e, nele, as regiōes de campos. Também foi dito a respeito da sua característica autárquica, cuja base populacional sustentava-se no trabalho escravo. Nada permite supor que a situação da mortalidade era muito diferente nessas unidades econômicas, a não ser que se considere a probabilidade de uma concentração populacional mais significativa.

Aliás, este seria o caso do segundo sistema demográfico proposto por Maria Luiza Marcílio para o Brasil do século XIX, e que foi ampliado para o século XVIII. ${ }^{90}$ Concerne às economias das plantations, isto é, economias alicerçadas por uma agricultura monocultora, latifundiária e integralmente dependente da "economia mundo". ${ }^{91}$ Integrado a esse modelo, grande parte da história social, econômica (e demográfica) da época colonial foi modelada pelo complexo do "engenho". Da mesma forma que nos latifúndios de criação no sul, sua estrutura fundamentava-se mais do que nunca no eixo senhorial-escravocrata - no topo, a administração e, na base, a mão-de-obra escrava: num engenho "normal", não considerando as terras dos chamados "plantadores-de-cana", mais modestos, trabalhavam cerca de 60 a 100 escravos, chegando, às vezes, a 200. Misto de "fábrica" e "fazenda", funcionava também como uma autarcia, compreendendo sua estrutura ferreiros, carpinteiros, pedreiros especializados e técnicos na fabricação do açúcar. ${ }^{92}$ Parte da população, provavelmente cativos na maioria, era desviada da atividade econômica principal para cuidar da subsistência de toda a comunidade. A autora em referência julga que "as melhores terras e de acesso mais fácil eram obviamente utilizadas pela monocultura exportadora (cana, café, tabaco, algodão ou cacau), resultando numa alimentação desequilibrada e mais pobre em variedade e teor nutritivo" ${ }^{93}$

Assim, é plausível concordar que a mortalidade, em consequiência, fosse maior nesse sistema, dada a vulnerabilidade relacionada às disseminações 
de epidemias e à carência alimentar. Vulnerabilidade que se ampliava em função da frágil base econômica do sistema, fundamentado na exploração de gêneros tropicais para exportação e dependente da demanda dos centros europeus. Portanto, as alternâncias de ciclos, da prosperidade e ruína decorrentes das flutuações econômicas, repercutiam socialmente. "Em cada fase descendente, desfaz-se um pedaço da estrutura colonial, desagrega-se a parte da sociedade atingida pela crise" ${ }^{\prime 4}$ - geralmente a menos capacitada para subsistir no sistema. Daí se explica, em parte pelo menos, a imensa população flutuante daquelas classes “intermédias”, sem lugar no sistema produtivo agroexportador, "cuja indefinição social foi, aos poucos, assumindo o caráter de desclassificação". ${ }^{9}$

De maneira geral, é provável que o menor crescimento vegetativo das regiōes de plantations, resultado de uma menor fecundidade e de uma mortalidade que poderia ser classificada como "alta-alta" (em função da densidade da população, vulnerabilidade maior às epidemias, doenças infecciosas e parasitárias, combinado com qualidade inferior da dieta alimentar) fosse compensada pela incidência de migrantes (tanto oriundos do exterior como de dentro da colônia).

Fazendo algumas distinções possíveis, no alto da escala social no engenho, encontrava-se uma elite, cujos membros nem sempre viviam na fazenda. Em síntese, essas camadas apresentavam crescimento natural importante, que se completava com o ingresso contínuo de novos componentes chegados da Europa. Fruto, evidentemente, de uma alta fecundidade mas, também, de uma mortalidade mais benigna ("alta-baixa"), considerando as melhores condições de vida das famílias de elite. ${ }^{96}$

Todavia, é muito provável que o principal fator das diferenças com as regiões de subsistência radicava-se na relativa concentração populacional das plantations, principalmente de cativos. A literatura tem mostrado resultados de pesquisas que indicam uma mortalidade extremamente elevada neste tipo de população aplicada e dedicada a uma agricultura tropical de exportação, o que deveria repercutir na população livre das plantations. Assim, o terceiro sistema, o das populações escravas, caracterizava-se principalmente pela ocorrência de surtos epidêmicos devastadores, mais comumente de varíolas e, principalmente após 1850, de febre amarela. 
Apesar das dificuldades para qualquer estimativa, um estudo, pelo menos, é bastante confiável como indicação: refere-se à avaliação de uma esperança de vida de 18,3 anos para escravos do sexo masculino, comparados aos 27,4 anos calculados para a população total das grandes plantações. ${ }^{97}$ De maneira geral, esta população estava submetida a condições piores de insalubridade, de subnutrição e de ausência de assistência médica que já afetavam, normalmente, a maioria da população livre. Finalmente, ao se considerar a mortalidade e a morbidade entre os escravos, deve-se distinguir a população nascida na África, menos protegida a doenças novas.

Mais difícil, ainda, são os cálculos relacionados à nupcialidade e à fecundidade entre os escravos. O que se conclui a respeito, de qualquer modo, é o óbvio: maiores inibições para o casamento entre escravos do que entre os livres - com variaçóes regionais -, o que impactava uma possível estabilidade na formação de famílias e na vida familiar. ${ }^{98}$ A descrição deste regime completa-se pela possível ocorrência de uma natalidade insignificante:

Martinho de Mendonça [governador da capitania de Minas Gerais entre maio de 1736 e dezembro de 1737], depois de fazer exaustivas investigações em Minas Gerais, no ano de 1734, declarou que os senhores não esperavam, normalmente, conseguir mais de doze anos de trabalho dos escravos jovens que compravam. Acrescentava que a cifra de natalidade mostrava-se muito baixa entre eles - 'nem a fecundidade das negras he atendivel, pella pouca que tem mulheres vulgarmente prostituidas, achaques e mortes de infancia nos negrinhos'. A baixa cifra de fertilidade (sic) dos escravos das minas e das plantações, foi notada por Burton, cento e trinta anos depois, quando o tratamento que lhes davam melhorara consideravelmente. Tal esterilidade relativa contrastava com a fecundidade das amantes negras e mulatas dos brancos, nas casas das vilas e do interior, e não precisa ser esmiuçada aqui. ${ }^{99}$

Uma discussão a respeito poderia classificar a opinião acima como controversa. Qual seria o nível "baixo" da fecundidade entre as mulheres escravas, considerando as difíceis condições de vida dos cativos? ${ }^{100}$ Até que ponto as estimativas que se têm não subestimam a natalidade, ao não considerarem adequadamente - essa é uma questão difícil - os números relativos a alforrias e mortalidade infantil e de crianças, bastante elevada? Dadas as dificuldades de cálculo, seria possível situar a fecundidade escrava 
numa ordem de 35 a 50 por cem mulheres. Na ausência de números mais precisos, qualquer tendência para se pensar muito para mais ou muito para menos está relacionada a uma questão, diga-se, político-ideológica. De um lado, a relação entre a fecundidade e as condições de vida escrava e, nesse sentido, fica ainda outra pergunta: até que ponto seria possível pensar que a mulher cativa não seria dada a "agir", no sentido de diminuir a sua prole? De outro lado, há que se considerar os próprios costumes africanos de prolongar a lactação como explicação na variedade de fatores que incidiam sobre a baixa fecundidade escrava. ${ }^{101}$

De qualquer modo, mesmo catastrófica, "parte da 'perda' da população africana era conseqüência da transferência para a condição de pessoa de cor livre" ${ }^{102}$ Se a isso se agrega o preço baixo do escravo, em função do favorecimento do tráfico, ${ }^{103}$ aliado a uma razão de sexo predominantemente masculina e o custo e risco de uma atividade "criatória" de força de trabalho escrava, ter-se-ia uma explicação razoável para a incapacidade da autoreprodução neste subgrupo populacional ${ }^{104}$ - o que parece ser contraditório ao que se poderia imaginar como um regime demográfico "escravo" coerente.

Talvez seja necessário levar em conta que, muitas vezes, os três sistemas interpenetravam-se mais ou menos, conforme a região, dependendo evidentemente da densidade demográfica local, da dinâmica econômica, da cultura regional, e assim por diante ${ }^{105}$ - mesmo porque, é necessário frisar, todas as economias regionais dependeram, em grau variado, do cativo africano e a própria estrutura ocupacional urbana (atividades artesanais de caráter doméstico e familiar, atividades especializadas e não-especializadas) era bastante tributária do trabalho escravo.

Essa interpenetração, do ponto de vista demográfico, também poderia traduzir-se em "migraçôes", relacionadas às transferências inter-regionais da força de trabalho escrava. Isto era conseqüência do comércio escravagista entre as diversas regiões do país e resultava de diversas variáveis, tais como a força da demanda de mão-de-obra nas culturas de café no Sudeste, a desigual distribuição na colônia e no país de crioulos e africanos, histórias mais ou menos prolongadas de alforrias e miscigenaçóes etc., mudáveis no contexto brasileiro. ${ }^{106} \mathrm{Tal}$ fato era evidente no sistema das plantations: quando das crises de mercado e as flutuações da economia, 
verificava-se "uma mobilidade espacial igualmente mais pronunciada, constituida pela saida de individuos desse setor". ${ }^{107}$

Deve ser salientado que a problematização de uma mortalidade escrava deve considerar a especificidade do grupo populacional, o que exige um tratamento à parte. Além disso, à medida que há uma aproximação de um passado menos distante, essa população gradativamente desaparece enquanto categoria jurídica. Libertando-se da escravidão, engrossa, na mesma medida, a população pobre e miserável que, do ponto de vista social e econômico, não estava muito distante do escravo.

Também deve ser enfatizado mais uma vez: o cenário colonial era conformado pela permanência de uma estrutura social extremamente hierarquizada que marcava a fundo a sociedade colonial brasileira. Sua relativa duração interferiria de forma negativa na dinâmica das relações sociais que caracterizaram o processo de mudanças estruturais no século XIX. Enfim, na permanência de uma população pobre que tentava sobreviver em roças, numa estrutura fundiária que também se modernizava paulatinamente, no litoral e no interior; na "posse" tradicional conflitando com novas noções de propriedade, geridas pelas elites, tanto no norte como nos campos do Brasil meridional.

Resta, ainda, dizer algo a respeito dos centros urbanos. É sabido que boa parte da população brasileira tradicional encontrava-se concentrada nas grandes cidades da época, ${ }^{108}$ nas vilas e povoações do litoral (incluído aqui as aglomerações relacionadas aos engenhos). Evidentemente, têm-se as cidades de mineração, ${ }^{109}$ mais para o interior (além, naturalmente, de São Paulo de Piratininga). Apesar da importância política e econômica dessas últimas, constituem, do ponto de vista populacional, exceções. As evidências assinalam que a mortalidade nas cidades não só era alta, mas também era marcada por surtos epidêmicos importantes, ${ }^{110}$ como de varíola, febre amarela, ou cólera. Estes parecem tornar-se cada vez mais freqüentes a partir da segunda metade do século XIX, elevando os picos de óbitos nas vilas e cidades, principalmente estas últimas. As cidades litorâneas, por sua vez, recebiam, entre outros produtos de importação, epidemias trazidas da Europa e da África. É claro, o quadro se deteriorava rapidamente nessas ocasiōes em virtude da concentração populacional que facilitava sobremaneira o contágio, agravado pelas terríveis condiçōes sanitárias e de sanea- 
mento. De modo que, finalmente, o crescimento das cidades sempre foi resultado da imigração, pois o saldo "vegetativo", no passado colonial brasileiro e século XIX, era negativo. Ações mais efetivas, oriundas de diversas formas de intervenção do Estado, deveriam esperar a segunda metade do século XIX.

Algumas palavras, ainda, para finalizar esta seção. Muitos trabalhos recentes têm mencionado taxas e índices demográficos de mortalidade para o passado brasileiro. As diferenças e o caráter hipotético dessas cifras são evidentes, e não se vê vantagem em tumultuar o texto com estes números. Ainda, fundamentados nas hipóteses dos regimes demográficos brasileiros diferenciados no passado, ficou implícito - pelo menos, essa era a intenção - uma escala diferencial da mortalidade, mas sem a desejável aventura da quantificação.

Por ora, deve-se guardar os números mencionados para a região de Curitiba. Todavia, é necessário ter presente o fato de que mesmo aqueles terríveis índices poderiam ser piores para regiōes mais quentes ao norte e ao litoral. Desta maneira, a mortalidade no planalto curitibano seria mais benigna, e os novecentos metros da diferença de altitude e a barreira formada pelas escarpas da Serra do Mar deveriam causar maior efeito no quadro epidemiológico da população, do que os quase trinta quilômetros a vol d'oiseau que separam um patamar do outro. ${ }^{11}$

Este artigo começa a terminar, talvez reforçando algumas generalizações. Entretanto, a pretensão é orientar "nortes", e - espera-se - algumas produtivas especulaçôes. Por certo, a mortalidade era maior entre a população urbana do litoral; num grau um pouco menor, entre os habitantes espalhados mais ou menos densamente nas faixas costeiras do território colonial. Com base nessa constatação, e à medida que a sociedade relativamente urbanizava-se na segunda metade do século XIX, é de se perguntar ainda se a situação não teria se deteriorado em relação ao século XVIII. Dessa maneira, numa visão panorâmica muito ampla, dir-se-ia que, por força dos "progressos" econômicos da época, a mortalidade teria aumentado, antes de começar a diminuir por influência dos avanços relativos à 
chamada "transição demográfica brasileira". Não existem dados para referendar tal hipótese, que se funda, simplesmente, no bom senso: radica-se nas evidências de um relativo isolamento - tanto mais quanto mais se aprofunda o passado -, o que salvava parte dos habitantes do interior e, mesmo, de algumas regiōes de menor densidade demográfica do litoral, das crises epidêmicas que, vez ou outra, assolavam parte dos "colonos".

De um lado, o comércio era pouco. De outro, o movimento de navios ligando a colônia com o tráfico epidêmico só viria a aumentar no século XIX. Além do mais, grande parte dos indivíduos comiam o que plantavam, o que era complementado em níveis diversos e regionais pela pesca, coleta ou pastoreio. Com efeito, uma mortalidade "alta-baixa" nessas regiōes mais afastadas seria o resultado também de ausências de "fomes" e, melhor ainda, de uma dieta mais bem balanceada. Eram os caiçaras do litoral, os diversos tipos de "bastardos" do interior, e os descendentes de imigrantes açorianos mais ao sul, homogeneizados por uma espécie de "civilização da mandioca" - do litoral ao norte -, e de uma "civilização do milho", mais ao interior e ao sul, que garantia o sustento básico dessas populações.

Imagino, ao começar a pensar numa conclusão para este artigo, quais seriam os componentes que poderiam especificar um regime demográfico do tipo colonial. Procurei, neste texto - reconheço, nem sempre de maneira muito objetiva -, designar as variáveis de um modelo. Refletindo, creio que está faltando, neste final, à luz do que o artigo sugere, contrapor ao isolamento como fator "negativo" um fator "positivo", representado pela mortalidade contextualizada pela violência. ${ }^{112}$ Característica da "aventura” colonial e dos subgrupos populacionais que viviam na frente fronteiriça de ocupação, a violência deveria abreviar, talvez de forma importante, a vida dos homens - e mulheres - que habitavam a fronteira e, principalmente, dos sertanistas.

Hipóteses nesse sentido - e não mais do que isso, pois não é possível, no estado atual da questão, considerar evidências empíricas - reforçam a perspectiva de um regime demográfico de "alta pressão" que, de modo geral, deveria tipificar as populaçóes mais móveis e ou que viviam nas regiōes que limitavam as possessões portuguesas na América. De maneira igual, traduzem modesta esperança de vida, que poderia igualar-se a índices a serem 
calculados para as regiões urbanas. Mas, oriunda de fatores bem diferenciados - mais uma vez, chamo a atenção para a necessidade de se considerar regimes demográficos restritos para a época colonial.

De um modo ou de outro, não se podia contar viver muito naquela época. Tocando na ferida, uma parcela importante das crianças nascidas nunca chegava à idade adulta. Repetindo um velho refrão entre os historiadores, também na sociedade brasileira tradicional a morte estava no centro da vida! E assim, os efeitos da mortalidade eram mais ou menos compensados por uma reprodução humana muitas vezes iniciada precocemente pelos casais, a partir de uniōes legítimas ou consensuais relativamente estáveis. Em conseqüência, e como regra geral, o crescimento vegetativo da população livre brasileira colonial foi quase sempre relativamente elevado, no principal em regióes de economia de subsistência e de criação de gado. As taxas de crescimento seriam sempre superiores "e ao redor de 1,0\% ao ano, em média". ${ }^{113}$ Portanto, taxas bem mais significativas do que aquelas que traduzem uma média geralmente aceita para as populaçōes européias tradicionais, de $0,2 \%$ a $0,5 \%$ ao ano. ${ }^{114}$

Esses números, porém, são bem menos expressivos do que aqueles que traduziriam a pujança demográfica latino-americana em geral, que estariam próximos dos 2,0\%. ${ }^{115}$ Os índices brasileiros, ainda mais, não teriam sido alterados no decorrer do século XIX, mesmo com a hipótese de um aumento da mortalidade, em virtude do incremento populacional gerado pela inserção dos imigrantes estrangeiros na população. Mas esta é outra história, que se desenvolve em outro artigo.

Finalizando, os dados mencionados resultam de estimativas agregadas. É preciso, de novo, chamar a atenção para a imensidão do território americano e, em especial, para a extensão dos domínios portugueses na América. Considere-se, por exemplo, a problemática bastante complexa da dinâmica demográfica européia, entremeando modelos hipotéticos diferenciados e que têm sido comprovado estatisticamente. ${ }^{116}$ É fácil concluir, a partir daí, que toda uma discussão, fundada em evidências empíricas, ainda está para ser feita na historiografia brasileira. Dessa maneira, entre outras interrogações, até que ponto regimes demográficos restritos, na América portuguesa, traduziam sistemas relativamente "homeostáticos"? Quais os mecanismos pertinentes às instituições "coloniais" que poderiam explicar 
a dinâmica da população colonial? Será que seria possível imaginar, antes ou paralelamente à constituição de comunidades "camponesas", um modelo individualista característico da "aventura"? 117 E assim por diante...

\section{Conclusões}

Ao introduzir o artigo, o leitor foi alertado para o fato de que não se pretendia fazer uma espécie de "história regional" - e nem, é preciso agregar, uma "história local". Contudo, centrando estrategicamente o foco nos campos paranaenses, é possível que se tenha a impressão de um certo desbalanceamento nessa direção. Ainda mais porque foi enfatizado, no contraponto da estabilidade, a "aventura" colonial no interior brasileiro e a "desqualificação" social e mobilidade (leia-se, instabilidade) dos mestiços que fizeram grande parte dessa história. Todavia, é de acreditar, por outro lado, que foram lançados alguns elementos de uma problemática para se construir as características de alguns regimes - ou sistemas - demográficos do passado, para além daqueles avançados, inovadoramente, por Maria Luiza Marcílio.

Tendo claros estes objetivos, a observação foi centrada no século XVIII; estrategicamente, enfoca uma "família" que - a documentação o comprova - viveu, nessa época, no planalto curitibano, provavelmente desenvolvendo uma produção doméstica fundada, em grande parte, num regime de "agricultura de subsistência” muito particular. Desse ângulo, é possível detectar uma linha móvel de sedentarização, que tem como variáveis tempo e espaço. Gregório e Anna Maria se inseriam nessa ampla fronteira, consistente com o desenvolvimento de povoaçóes que seguem o rastro dos sertanistas mas que evidenciam, cada vez mais, a especialização econômica da região. Fronteira de estabilidade que parte das regiôes mais definidas economicamente no litoral para o sertão ainda inexplorado. Seus limites eram ainda imprecisos e precisavam ser determinados pela ocupação demográfica e econômica, em detrimento do indígena. Ângulo, finalmente, do qual é possível vislumbrar não só as "fronteiras" que se estendiam do Sul ao Norte, mas até, forçando a vista, os confins do próprio Império português, não escapando ao observador algumas originalidades no passado demográfico brasileiro. Sem dúvida, seu principal componente é a pró- 
pria colonização de características, cada vez mais, mercantilistas e fundadas no escravismo.

O povoamento, via mestiçagem, inserido numa cultura misógina ${ }^{118}$ e fundada na "posse", atendia aos ditames institucionais; a estes, amoldamse os valores da sociedade que se origina no ambiente colonial. Mestiçagem que não traduz simplesmente o resultado do intercurso sexual do português com a índia (a "miscigenação"), mas uma relação cultural. Mestiçagem de tabus, de costumes mágicos, de representaçôes, agigantados de certa forma pelo processo do "pioneirismo aventureiro" da colonização. Mestiçagem que resulta numa combinação bastante original da alimentação, fecundidade e mortalidade. Mestiçagem que interferia na maior ou menor estabilidade do casal, na idade do início da união, possibilidades de impedimento, nas práticas cotidianas articuladas às relações sexuais, à estrutura familiar, às práticas endogâmicas e exogâmicas - às quais se soma, como um todo, o clima de "guerra" próprio do sistema colonizador. Ainda agregue-se, a um tal regime cultural, variáveis tais como a aceitação ou recusa das crianças, abortos ou abandono, duração da lactação, modalidades da primeira educação, destino dos viúvos, das viúvas e dos velhos. Mestiçagem, enfim, relacionada a uma esperança de vida, pois articulava-se à insuficiência ou profusão de recursos alimentares, ao ambiente geográfico (fauna, clima, topografia ...), às doenças endêmicas e epidêmicas, a certas formas de práticas médicas, ou a inexistência delas. ${ }^{119}$

Mestiçagem, "produto histórico dos latifúndios", ${ }^{120}$ mestiçagem indistinta da bastardia, tolerada, instigada ou, mesmo, favorecida pela Metrópole e pelas suas elites. Tolerância e/ou favorecimento que se estendia, no quadro de uma imigração feminina branca relativamente pouco numerosa, no estímulo do embarque em Portugal de elementos indesejáveis e parcelas desqualificadas: entre as mulheres, muitas "meretrizes". Esse também é o cenário que permite compreender a complacência da sociedade colonial em relação à própria prostituição, e à facilidade com que mulheres pobres e sós, na colônia, eram enquadradas nessa categoria. ${ }^{121}$ No contraponto, é fácil entender como os imigrantes brancos, homens e solteiros, mascates, cristãos novos, ou seja, o que for, traziam consigo um capital importante: sua cor. Ao vencerem a barreira dos preconceitos da elite senhorial e, principalmente, se enriquecendo, constituem gradativamente um 
bom partido para a reprodução dos filhos e herdeiros da sociedade patriarcal e escravocrata - muitos, descendentes dos primeiros mestiços da colônia. A eles eram dadas as virgens resguardadas, trancadas, isoladas, mantidas a distância da maioria da sociedade, mas inseridas na mesma paisagem cujo clima moral consentia, como banal, as relações "ilícitas", mancebas e concubinas; e, até, fechando os olhos à bigamia. Tudo era permitido a quem, condenado por antecipação, tinha que vencer o Purgatório.

A idéia da "posse" completa essa visão. Foi referido, de um lado, à terra (combinada, aqui e ali, com a "propriedade" - concessão de sesmarias, por exemplo, compondo o regime social e demográfico da elite colonial). Posse articulada à ocupação do solo e das suas riquezas, que estimulou o pioneiro, em vagas sucessivas e a partir de múltiplos centros de irradiação, a enfrentar a serra, a floresta, o aborígine, a encarar seus medos. Posse ligada ao maior ou menor isolamento, pelas rupturas que se fizeram com os núcleos iniciais. Posse inerente ao sistema escravista. Posse, finalmente, que resultou na destruição e sujeição de povos indígenas. Rematando, posse que resulta numa história demográfica - nem sempre, como se vê em toda parte, sinônimo de crescimento - ${ }^{122}$ que, de uma forma ou de outra, confirmou a ocupação diferenciada de um espaço.

Mas também quis-se enfatizar a "posse" de mulheres pelos homens, aguçada na mencionada misoginia e pelo "aventureirismo" característico das aquisições coloniais da Época Moderna. A posse definida pela conquista, sob a sombra do estatuto da escravidão. Posse, evidentemente, que viabilizava a colonização e que, portanto, era estimulada pelo Estado e, até certo ponto, consentida pela Igreja. E, até, "usada": é peculiar, por exemplo, o uso que párocos locais e bispos faziam do conceito de "escândalo", para enfatizar a proeminência sobre a população. ${ }^{123}$

O processo da colonização traduz estruturas sociais complexas, daí a dificuldade para se ir mais a fundo em qualquer generalização a respeito dos regimes populacionais implantados na colônia. Entretanto - e considerado como "dados" os sistemas demográficos propostos por Marcilio uma questão fundamental que foi colocada no texto refere-se à estabilidade da população. O modelo proposto está relacionado à singularidade histórica de uma sociedade "móvel", que se caracteriza inclusive por uma relativa instabilidade familiar e pelo contraponto, também original, de uma 
população mais estável instalada no litoral e, quase essencialmente, no Nordeste. Na extremidade, um modelo demográfico urbano, de fraco crescimento vegetativo, e cuja dinâmica baseava-se no ingresso constante de novos contingentes populacionais oriundos da imigração; mais ou menos no seu "interior", regimes demográficos "restritos", fundados seja na escravidão, seja em economias familiares de subsistência mais ou menos estáveis, seja na economia do gado. Regimes demográficos que se sucedem, se interpõem e se superpõem no tempo e no espaço. Que confrontam, em dicotomias complexas, "estabilidade" e "instabilidade", "aventura" e "trabalho", o "litoral" e o "planalto", "aglomerações urbanas" e a "rarefação sertaneja”, a "floresta" e o "campo"... No plural, estes tempos e espaços foram construídos pela distensão demográfica a partir das regiōes litorâneas (e de São Paulo da Piratininga), originando, em alguns momentos, outros sistemas irradiadores. O exemplo de Curitiba, lançando durante quase um século uma população e um modo de vida para o oeste até os campos de Guarapuava e Palmas, ${ }^{124}$ deve ser semelhante a inúmeros outros, e não só na história do Brasil.

O modelo também inclui, portanto, a mobilidade das próprias estruturas sociais que "migram"; em particular e no principal, em função das demandas da agricultura do açúcar (e outras). Estas, exigindo uma estabilidade que não era própria das populações do sertão, avançam gradativamente, definindo fronteiras de modo igual móveis que progridem para o sul-sudeste, no interior "paulista"; mais tarde, essa cultura seria substituída pelas exigências de "estabilidade" geradas pela monocultura do café. Essa "migração" da estabilidade, ou do "trabalho" - segundo a tipologia proposta por Sérgio Buarque de Holanda -, e que expulsa gradualmente a aventura do descobrimento, da riqueza fácil proporcionados pela preagem e pela predagem, é datada: coincide no Brasil com a decadência das minas e com o revigoramento da agricultura de exportação no final do XVIII. No mundo ocidental, com o início do desenvolvimento do "liberalismo". Mas essa já é outra história. 
Para completar essas reflexões finais que se fazem à guisa de conclusão, talvez seja útil, ainda, "mapear", como exercício e em tintas muito rápidas, um e outro regime demográfico restrito que vigorou no Brasil colonial - alguns certamente até a metade do século XIX. Todos teriam, como denominadores comuns, uma combinação variável dos elementos gerais acima enunciados. Nesse sentido, os estudos empíricos relativos à freguesia curitibana levam a algumas reflexões, relacionadas ao papel, neste regime demográfico ou em outros, da alimentação e da amamentação, combinado com diferentes fatores ambientais e outras variáveis, tais como as peculiaridades da distribuição das idades das mães (e dos pais), no início da procriação (privilegiada, aqui, em detrimento do início da vida matrimonial, pelas razões apontadas no texto). Levam a refletir também quanto à maior ou menor mobilidade dos homens e na estabilidade do domicílio (e da família), conjugado com fatores tais como a mestiçagem biológica e cultural - e aqui valeria a pena considerar o que estas populações aprenderam dos indígenas em relação a métodos contraceptivos e sua efetiva utilização na vida matrimonial), o poder das instituiçôes no cotidiano familiar e, até mesmo, a maior ou menor interferência no lar pelo vigário de vigia - e o confessionário! Finalmente, ao valor que se dava às crianças numa sociedade que apenas vinha de, penosamente, se estabilizar e, para algumas famílias, às condições de transmissão do patrimônio e da concessão do dote - principalmente, para aqueles que tinham algum bem a ser valorizado (ou desvalorizado), pelo casamento.

O caráter incompleto dos enunciados que se seguem mostra a amplitude das questôes que poderiam se constituir numa pauta comum para a continuidade do estudo da história demográfica brasileira. Por outro lado, não seria ajuizado - pelo risco de cometer evidentes injustiças - arrolar uma bibliografia e pesquisadores cujos trabalhos poderiam constituir a base para se dar continuidade às interrogaçóes implícitas nos enunciados que seguem. Alguns poucos - é de reconhecer -, foram listados nas referências bibliográficas. Citemos alguns aspectos conclusivos:

- Em primeiro lugar, paulistas, vicentinos e santistas, se aventuraram no sertão e, assim, ajudaram a conhecer, povoar e conquistar o interior brasileiro. Suas características teriam, como signo e denominador comum, um tipo de "migração" que, por meio dos seus fluxos, construíam cami- 
nhos e plantavam arraiais. Migração que se traduzia no brotar de vilarejos novos, o que não "exprime forçosamente um aumento no número de habitantes de toda a região", mas a escassez, "no termo da vila madre, de espaço disponivel e acessivel para a abertura de roçados, quando todo ele, ou a maior parte, já tenha donos, ou por qualquer outro motivo se acha sem préstimo para as lavouras". ${ }^{125}$

Nos acampamentos, quedavam-se um tempo, ou se estabeleciam mais permanentemente; ou iam adiante, originando novos territórios a serem conhecidos, povoados e conquistados. Trata-se, como muitos autores já descreveram, de migrações em "família" - família em geral fundada na mestiçagem, no cruzamento sucessivo que se originou da relação entre o branco e o indígena. Junto aos brancos e mamelucos, acompanham este estilo de vida mais ou menos nômade os escravos, índios e negros, que servem de mão-de-obra e para reprodução. A lei desses "fragmentos do latifúndios" - numa feliz expressão de Oliveira Vianna ${ }^{126}$ - é a lei do senhor, do conquistador, regido pela mentalidade, moralidade e valores impostos por uma situação muito peculiar.

- No "interior" do sistema demográfico da plantation, cujo âmbito poderia ser generalizado para uma grande parte do sistema colonial até o século XVIII, talvez fosse conveniente destacar de maneira adequada a autarcia do "engenho", ao mesmo tempo fábrica e lavoura. Ali, regimes demográficos "restritos" seriam concernentes às camadas senhoriais e, no outro extremo, ao escravo da plantation. No final do século, e com o desenvolvimento da cultura cafeeira, um regime demográfico também decorrente se instalaria em função da própria "migração" do café. Só para traçar uma característica, é possível imaginar um regime de mortalidade original, fundado na concentração em que viviam os escravos nas lavouras e engenhos. Embora a mortalidade escrava seja característica, é possível que a concentração demográfica, típica dos engenhos, tenha facilitado de maneira peculiar a transmissão de epidemias.

- Qualquer consideração a um regime demográfico das plantations deve levar em conta o regime restrito da demografia escrava, a complexidade e as flutuações da produção e exportação do açúcar, bem como o volume e custo do tráfico. ${ }^{127}$ Deve ser considerado, ainda, na continuidade do fluxo e seu volume o reforço da cultura africana no Brasil (com variaçôes regio- 
nais, Angola, Benguela, Costa da Mina ...) e, em conseqüência, a continuidade e ou rupturas de valores relacionados. $\mathrm{Na}$ relação fluxo e volume, acima mencionado, função geralmente do desenvolvimento da economia, devem ser levadas em conta, igualmente, as razões de masculinidade e a estrutura etária da população africana. ${ }^{128}$ Finalmente, é importante mencionar as possibilidades postas pelo casamento, famílias escravas mais ou menos estáveis e as próprias características das senzalas. ${ }^{129}$

- Quanto à elite senhorial, as ponderações relativas a um regime demográfico restrito a estas camadas da sociedade colonial brasileira devem agregar o fato primeiro de que havia um patrimônio a zelar e a transmitir se possível, aumentado. O que se fazia por estratégias diversas no âmbito de famílias geralmente complexas. Dentre elas, uma reprodução adequada, um relativo retardamento para o matrimônio dos varóes, aliado ao casamento precoce feminino - significando uma diferença de idade expressiva entre os cônjuges - e a uma esperança de vida mais alta (que chegava mais ou menos aos 50 anos de idade) em relação ao conjunto da população (mortalidade "alta-baixa"). Isso pode ser afirmado segundo o que parecem indicar os dados relativos aos senhores de engenho do oeste paulista, para a primeira metade do século XVIII e início do XIX. E também pela opção da consangüinidade nos arranjos matrimoniais, "fator que atuava conjuntamente a outros elementos, que, da mesma forma, pesavam no momento da tomada de decisão". Outras opçóes, naturalmente, estavam relacionadas a alianças economicamente vantajosas, o que levava a práticas endogâmicas, sociais e geográficas. A família de elite era menos fecunda, mas - pelo fato de que os filhos permaneciam maior tempo junto aos pais - mais extensa. ${ }^{130}$

Por várias razōes, os regimes demográficos possivelmente fundados nas autarcias do gado ao Sul e ao Centro são ligadas às plantations. Destaco a estrutura fundada na mesma tríade: latifúndio-patriarcalismo-escravidão. Entretanto, talvez as diferenças sejam mais importantes do que as semelhanças, dado o caráter consideravelmente nômade dos seus componentes e a densidade demográfica mais rala da estância. O gado avança, e com ele, o senhor e sua família, os agregados, os peões, os mestiços e negociantes ligados ao sistema. E os escravos, cuja tarefa, diferentemente das plantations, era prover a alimentação e produtos básicos ao conjunto dos residentes. Existem valores próprios nessa "cultura estanciera" que devem ser eviden- 
ciados para se compreender regimes demográficos concernentes. Existe um clima de guerra, em face das tensões criadas pela friç̧ão com o belicoso aborígine. Subsiste articulada uma mentalidade comercial, que se desenvolve com o tropeirismo - teria a comunidade dos tropeiros um regime demográfico original, que valeria ser destacado? Enfim, se for correta a imagem clássica de O. Vianna, existiria um orgulho, uma "nobreza” própria do vaqueiro, que se originalizaria no Sul, com os gaúchos, com os vaqueiros curitibanos, com os nordestinos. A colônia, nessa paisagem, evidentemente não é a mesma do litoral.

- A partir do sistema demográfico das economias de subsistência, já enunciado para o século XIX por Maria Luiza Marcílio, é possível pensar em algumas especificidades que valeriam a pena destacar. Sem dúvida, estruturada em volta e em função das plantations e das estâncias, pessoas, famílias, grupos enfim, dedicavam-se a viver do que plantavam e, esporadicamente, vender o excedente nos povoados ou fazendas próximas. Ligadas à expansão paulista, acima referida, comunidades de indivíduos também viviam dessa maneira, tanto no Sul, como em volta ou próximos das minas, mormente após o esgotamento dos aluviōes. Regimes demográficos, aqui e ali, ligados às atividades (relativamente) sazonais locais: o mate e a cochonilha, por exemplo, no Paraná e Santa Catarina.

- Aparentado, mas principalmente original, um regime demográfico restrito pode ser tipificado para os colonos que se aventuravam na colheita das "drogas do sertão" e outros produtos demandados pela Metrópole e pelo litoral da colônia, principalmente na Amazônia, estabelecendo com isso, por exemplo, uma relação muito especial com os indígenas. Sistema interessante também para ajudar a compreender as migraçóes que se fariam na região, em função da exploração da borracha no século XIX.

- Dadas as particularidades climáticas da região, seria possível postular um sistema demográfico fundado no regime de secas do sertão nordestino, articulado às economias de subsistência e à criação de gado, caracterizado, no principal, pela grande mobilidade gerada pelas fomes periódicas que assolavam a região. ${ }^{131}$

- No Sul, os açorianos sem dúvida devem ser destacados. A memória dessa história demográfica original deve ser buscada nos próprios Açores e na Madeira e nos fatores muito específicos que levaram à emigração dos 
ilhotas. Memória que deve registrar, entre outros, formas de organização familiar e do domicílio e sistemas de parentesco, rompidos, de certa forma, com as migraçóes e que foram reconstruídos nas economias de regime familiar reconstruídas na colônia.

- Ainda, se destacaria, num sistema demográfico das economias urbanas mais próprias do litoral e, em grande parte, fundadas na dependência do comércio e dos portos - e de contatos com as nações amigas, principalmente após 1808 - a cultura urbana mineira. ${ }^{132}$ Em função da mobilidade que inaugura o sistema, e que cria valores pertinentes, este regime poderia ser aparentado com o "paulista”, antes enunciado. É possível acreditar que o estado atual dos conhecimentos a respeito, e a profusão de fontes existentes para as regiōes de Minas, Goiás e Mato Grosso, permitiriam equacionar melhor um regime demográfico "mineiro", cuja base, a partir da decadência das minas, desenvolve-se em função de algumas especificidades regionais muito características. Para terminar esse breve arrolamento, no interior de um sistema de economias urbanas, poderia ser destacado, fugindo um pouco à generalização fácil, um regime demográfico urbano restrito, característico das vilas do interior, tais como São Paulo de Piratininga.

\section{ANEXO}

Tabela 1 - A "Família Gonçalves". Consistência das Informações obtidas a partir dos Registros Paroquiais e das Listas Nominativas de Habitantes. Curitiba, século XVIII

(p.72) 


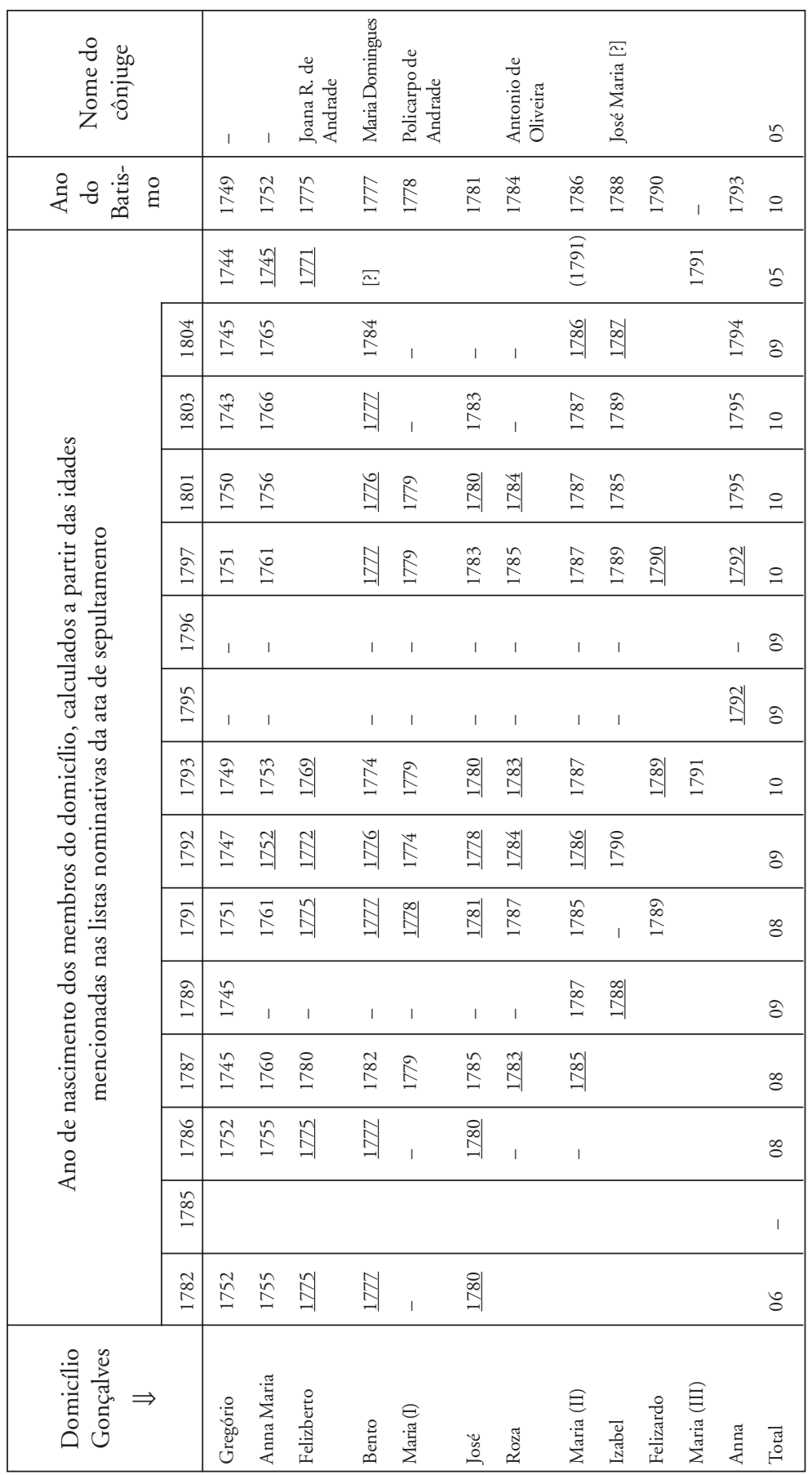

TOPOI, v. 4, n. 7, jul.-dez. 2003, pp. 222-275. 
Observações:

- Certas listas omitem informações referentes à idade - o ano estimado de nascimento foi substituído por um traço [-].

- Na lista de 1785 não foi encontrado o domicílio de Gregório Gonçalves.

- Para estimar os prováveis anos de nascimento dos membros do domicílio, devemos comparar as informações obtidas das listas e dos registros paroquiais. Desde logo, é possível eliminar os dados que informam anos de nascimento ocorridos após o batismo (antes é possível, pois sabemos que, apesar das disposições das Constituições do Arcebispado da Bahia, sempre havia a possibilidade - mais ou menos remota, conforme o caso de uma criança ser batizada um pouco mais velha). Da mesma forma, podemos eliminar prováveis anos de nascimento para membros do domicílio que nasceram antes de um irmão mais velho; finalmente, podemos também desconsiderar as informaçôes relativas às crianças que teriam nascido antes do ano do casamento dos pais. Eliminadas estas distorçóes, restaram os anos de nascimentos sublinhados. A partir destes critérios, tudo indica que a melhor lista corresponde àquela do ano de 1792 e, em conseqüência, estimou-se que Gregório Gonçalves teria nascido em 1747. Posteriormente, nos "Autos de Casamento", processo que resultou nas proclamas, o vigário da Paróquia N. Sra. Do Pilar, em Antonina, informa que teria sido batizado em 17 de maio de 1749, ano mais provável do seu nascimento.

\section{Notas}

${ }^{1}$ MARTIUS, Carlos Frederico. Como se deve escrever a história do Brasil. Revista do IHGB, 1(10);149-57, 1841, p. 408.

${ }^{2}$ ABREU, J. Capistrano de. Caminhos antigos e povoamento do Brasil. 4ed. Rio de Janeiro: Civilização Brasileira; Brasília: MEC/INL, 1975.

${ }^{3}$ RIBEIRO, João. História do Brasil. (5aed.) Rio de Janeiro: Francisco Alves, 1914, pp. 23-4.

${ }^{4}$ MACHADO, Brasil Pinheiro. Problemática da cidade colonial brasileira. História: questões \& debates, 6(10):3-23, jun. 1985, p. 17.

${ }^{5}$ Cf. KREAGER, Philip. Demographic regimes as cultural systems. In: COLEMAN, D \& SCHOFIELD, R. (eds.). The state of Population Theory. Nova York: Basil Blackwell Ltd., 1986. 
${ }^{6}$ De forma conservadora, estima-se que no século XVIII devem ter saído de Portugal por volta de 400 mil migrantes [MARCÍLIO, Maria Luiza, A população do Brasil Colonial. In: BETHEL, Leslie. História da América latina: A América Latina Colonial, vol. II. São Paulo: Edit. da USP; Brasília, DF: Fundação Alexandre de Gusmão, 1999, 322; FURTADO, Celso. Formação econômica do Brasil. 23a ed. São Paulo: Editora Nacional, 1989, 81; SOUZA, Laura de Mello e. Desclassificados do ouro: a pobreza mineira no século XVIII. Rio de Janeiro: Graal, 1986, p. 24; PRADO JR., Caio. Formação do Brasil Contemporâneo. São Paulo: Brasiliense, 1996, 88].

${ }^{7}$ ALENCASTRO, Luiz Felipe de. Singularidade do Brasil. In: O trato dos viventes. Formação do Brasil no Atlântico Sul; séculos XVI e XVII. São Paulo: Cia. das Letras, 2000:340-1 e 337. Ver, também, ABREU, op. cit.1975:57-8.

${ }^{8}$ Cf. GOLDANI, Ana Maria. O regime demográfico brasileiro nos anos 90: desigualdades, restriçôes e oportunidades demográficas. In: GALVĀO, Loren \& DÍAS, Juan (org.). Saúde sexual e reprodutiva no Brasil. (Local): Hucitec/Population Council, 25-26.

${ }^{9}$ Não se quer entrar aqui na rica polêmica que poderia ser ensejada por comentário conclusivo de ALENCASTRO em trabalho recente: "A continuidade da história colonial não coincide com a continuidade do território colonial. A transparência intermitente de uma matriz colonial que é distinta da unidade nacional brasileira inverte a cronologia e sugere uma seqüência histórica alternada: o século XIX está mais perto do século XVII do que do XVIII" op. cit., p. 353.

${ }^{10}$ FURTADO. op. cit., p. 11/74.

${ }^{11}$ ALENCASTRO. op. cit., pp. 330 e 334.

${ }^{12}$ SOUZA. op. cit, p. 57.

${ }^{13}$ A comparação é feita com Angola, onde não haveria "miscigenação": "o colonato local tinha filhos com as negras. Mas não havia mestiçagem: quando os pais se afastavam ou morriam, as mães retornavam às suas aldeias com seus filhos mulatos, levando-os de volta à comunidade tradicional è à fricanização" [ALENCASTRO, op. cit. p. 350-1].

${ }^{14}$ SIMONSEN, Roberto C. História econômica do Brasil (1500/1820). São Paulo: Cia. Editora Nacional, 1969, p.135. (6ª ed.)

${ }^{15}$ BOXER, Charles R. A idade do ouro do Brasil: dores de crescimento de uma sociedade colonial. $3^{\mathrm{a}}$ ed. Rio de Janeiro: Nova Fronteira, 2000, p. 35.

${ }^{16}$ Deixo de lado uma discussão mais aprofundada do assunto, indicando o texto de TORRES-LONDOÑO, a respeito das "mulheres da terra e seu destino: escravidão e mancebia". TORRES-LONDOÑO, Fernando. A outra família. Concubinato, Igreja e escândalo na colônia. São Paulo: Edições Loyola, 1999: pp. 31-46. Da mesma forma, MAXWELL, Kenneth. A Amazônia e o fim dos jesuítas. Folha de S. Paulo; Mais! 26.08.2001, p. 15.

${ }^{17}$ ALENCASTRO, op. cit., p. 352.

${ }^{18}$ Diz-se das populações que não utilizam, pelo menos generalizadamente, métodos contraceptivos. 
${ }^{19}$ Casamentos. Livro 3 (1762-1784 - destinado a escravos, mulatos e bastardos). Paróquia de Nossa Senhora da Luz dos Pinhais de Curitiba, acervo da Catedral.

${ }^{20}$ A respeito da população mineira, BOXER dá atenção aos "garimpeiros", brancos ou de cor e livres. A marginalização desta categoria devia-se ao fato de que exerciam uma atividade ilícita (o garimpo de diamantes). Relativamente estáveis, na medida em que muitos tinham sua família "num arraial ou aldeia vizinha, e podia exercer o duplo papel de trabalhador legal e mineiro ilícito" [...] Praticamente, viviam lado a lado com escravos negros fugidos ("calhambolas") que também exerciam o garimpo e "muitas vezes tinham de matar gado e animais domésticos para se manterem vivos, e dai poderem ser classificados como bandidos e ladrôes [...]; viam-se freqüentemente contra todos os homens livres, e não tinham refúgio seguro a não ser no quilombo". BOXER, Charles R, op. cit. pp. 234-6. Nesse sentido, Sheila FARIA alerta para o cuidado em não se generalizar a qualificação dos andarilhos como "marginais" e "desclassificados", sob pena de se adotar premissas do pensamento dos grupos dominantes do período [FARIA, Sheila de Castro. A colônia em movimento; fortuna e família no cotidiano colonial. Rio de Janeiro: Nova Fronteira, 1998, pp. 108-9].

${ }^{21}$ SOUZA, op. cit. p. 63.

22 PRADO JR., op. cit. p. 1996:36.

${ }^{23}$ NADALIN, Sergio Odilon. A demografia numa perspectiva histórica. Belo Horizonte: Associação Brasileira de Estudos Populacionais (ABEP), 1994, p. 23.

${ }^{24}$ Gregório Gonsalves Fernz [Fernandez] Filho de Clemente Gonsalves natural de Cor ${ }^{a}$ cazado de Id de [28] annos estatura baixa cara comprida trigr cabelo pretto e Corredio sentou prassa em 9 de novembro de 1766 annos ["Mostra de 8 de abril (de) 1776" (terceira esquadra, Vila de Curitiba)].

${ }^{25}$ BOXER, op. cit., p. 284.

${ }^{26}$ OLIVEIRA VIANNA, F.J.. Populações meridionais do Brasil: história, organização, psicologia. 5ํㅡㄹ ed. Rio de Janeiro: José Olympio, v.1, 1952. pp. 119-20. Este autor também classificou as bandeiras em dois tipos: Primeiramente, as "bandeiras de guerra", constituído de "bandos sertanistas de simples exploração do sertão, de prêa ao índio, de caça ao ouro, de combate aos quilombos [...]". Ao se ultrapassar essa fase, as bandeiras de guerra transformam-se em "bandeiras de colonização", e o escravo negro e o mulato são preferidos, na sua constituição, ao mameluco e ao indígena [121].

${ }^{27}$ SCHWARTZ, Stuart B. O Brasil Colonial; 1580-1750: as grandes lavouras e as periferias. In: BETHEL, Leslie. História da América latina: A América Latina Colonial, vol. II. São Paulo: Edit. da USP; Brasília, DF: Fundação Alexandre de Gusmão, 1999a, pp. 384-5. ${ }^{28}$ Talvez em nenhum lugar este fato fosse tão evidente quanto na região das minas, em função da corrida do ouro: "O fato de tantas pessoas de ambos os sexos e de várias cores viverem no Brasil' a lei da Natureza', conforme vice-reis, bispos, magistrados e missionários estavam constantemente deplorando, deu origem a um enxame de mendigos sem lar, errantes $e$ vadios, que em parte alguma constituíram problema tão grande como para as autoridades de Minas Gerais." Expedientes diversos eram utilizados pelas autoridades, tais como deportar os piores para Angola. "Outro expediente predileto estava no alistar mulatos, negros, amerín- 
dios e mestiços livres em bandos armados, sob a direção dos chamados capitães-do-mato, que batiam a região rural em busca de escravos negros fugidos." [BOXER, op. cit., pp. 193-195]. ${ }^{29}$ É digno de nota, por exemplo, que em 1801, foram contabilizados 81 imigrantes portugueses em Curitiba. Número importante, se for considerado que em todo o litoral paranaense viviam 85 portugueses. BACELLAR, Carlos de Almeida Prado, Os reinóis na população paulista às vésperas da independência. XII Encontro Nacional de Estudos Populacionais. Caxambu: ABEP, 2000, pp. 7-9.

${ }^{30} \mathrm{Na}$ paróquia de Nossa Senhora da Luz dos Pinhais de Curitiba essa situação era tão especial que levou o vigário a distingui-la. Os casamentos, batismos e óbitos de escravos, administrados, forros e "bastardos" realizados durante o século XVIII mereciam um livro especial, separando-os dos registros dos eventos relativos aos de boa casta, "gente branca" e livre. Essa prática é, de certa forma, coerente com a designação de "bastardo", dada particularmente em São Paulo (que, naquela época, incluía os campos curitibanos). HOLLANDA, Sérgio Buarque de Caminhos e fronteiras. 2ª ed. Rio de Janeiro: J. Olympio, 1975, p. 144.

${ }^{31}$ Idades estimadas em função dos registros de batismo dos noivos. Para Gregório, essa informação foi recuperada nos Autos de Casamento (foi batizado em 17.05.1749, em Antonina, no litoral), Microfilmes, Rolo 12, do acervo do Cedope, Centro de Documentação e Pesquisa da História dos Domínios Portugueses, Departamento de História, UFPR. O documento original consta do acervo do Arquivo Dom Leopoldo Duarte, Cúria Metropolitana de São Paulo.

32 SOUZA, Antonio Candido de Mello e. Os parceiros do Rio Bonito: estudo sobre o caipira paulista e a transformação dos seus meios de vida. 5aㅡ. ed. São Paulo: Livraria Duas Cidades, 1979, p. 63.

${ }^{33}$ FRANCO, Maria Sylvia de Carvalho. Homens livres na ordem escravocrata. $4^{\underline{a}}$ ed. São Paulo: Fundação Editora da UNESP, 1997, p. 98. A autora continua: "Esse equilíbrio foi rompido e o correspondente estilo de vida perdeu-se como possibilidade regular de ajustamento social, com o desenvolvimento da exploração lucrativa da terra".

${ }^{34}$ SOUZA, op. cit. 1979, pp. 62-3.

${ }^{35}$ Termo tradicional, designando um "domicílio".

${ }^{36}$ BOXER, op. cit., pp. 283-4.

${ }^{37}$ VALENTIN, Agnaldo. Ouro paulista: estrutura domiciliar e posse de escravos em Apiaí, 1732 a 1798. Estudos Econômicos, São Paulo, 31(3):551-585, jul.-set. 2001, pp. 557-9;559. Não cabe neste espaço refazer a trajetória da pesquisa do autor. Sua pesquisa vai adiante, até o final do século XVIII (1798), com uma complexidade maior dos resultados que, no final das contas, corroboram as análises.

${ }^{38}$ Gregório inclui-se entre os chefes de domicílio da categoria "casal com filhos". Em 1776, esses fogos formavam $60,8 \%$ do total $(87,1 \%$ constituíam o total da população concentrada em domicílios "simples), e eram 54,5\% em 1785 (proporção total de domicílios simples contabilizados nesse recenseamento era 78,5\%). DE BONI, Maria Ignês Mancini. 
A população da Vila de Curitiba segundo as listas nominativas de habitantes; 1765-1785. Curitiba, Universidade Federal do Paraná, Dissertação de Mestrado,1974, p. 101.

${ }^{39}$ DE BONI, op. cit., p.101.

${ }^{40}$ DE BONI, op. cit., p.101.

${ }^{41}$ MARTINS, Romário. História do Paraná. (3ae ed.). Curitiba: Ed. Guaíra, s.d. p. 205.

${ }^{42} \mathrm{~A}$ área mencionada é estimada por PRADO JR., que coloca na regiāo aproximadamente 600 mil habitantes, no início do século XIX [PRADO JR., C. op. cit. p. 56]. Para incluir São Paulo e Paraná, simplesmente agregamos dados de tabela publicada por MARCÍLIO, Maria Luiza. Crescimento histórico da população brasileira até 1872. Cadernos CEBRAP, 16, 1973, p. 13.

${ }^{43}$ Maria Luiza MARCÍLIO aventa, para o século XIX, os seguintes "sistemas demográficos": (1) das economias de subsistência; (2) das economias das plantations; (3) das populações escravas; (4) das áreas urbanas [MARCÍLIO, Maria Luiza Sistemas demográficos no Brasil do século XIX. In: (org.) População \& sociedade. Evolução das sociedades pré-industriais. Petrópolis: Vozes, 1984:193-207]. Ao discutir esta questão, foi proposto pensá-la também para o século XVIII [NADALIN. op. cit. 85-93]; aliás, dir-se-ia que a própria autora em referência faz isso, ao recuperar implicitamente o tema em 1999.

${ }^{44}$ SOUZA, op. cit. 1979, P. 62.

${ }^{45}$ Idem, p. 75.

${ }^{46}$ FARIA. op. cit. p. 61-8. VAINFAS, Ronaldo. Trópico dos pecados; moral, sexualidade e Inquisição no Brasil. Rio de Janeiro: Campus, 1989, p. 101.

47 SILVA, Maria Beatriz Nizza da. Sistema de casamento no Brasil colonial. São Paulo: Queiroz, 1984, pp. 37-8.

${ }^{48}$ ALMEIDA, Ângela Mendes de. O gosto do pecado: casamento e sexualidade nos manuais de confissóes dos séculos XVI e XVII. Rio de Janeiro: Rocco, 1992, p. 125 (sem grifo no original). A não ser, naturalmente, que questōes de poder levassem determinado vigário a metamorfosear, ou a elevar, um comportamento relevado pela sociedade à categoria de "escândalo", um mau exemplo que deveria ser eliminado (a esse respeito, ver TORRESLONDOÑO. op. cit. 159 e seguintes). Luis Henrique MOTT comentou, num seminário na UFPR, há alguns anos: no clima pós-tridentino da Contra-Reforma, mais preocupante do que a mancebia era a possibilidade da bigamia, que atentava contra o próprio sacramento do matrimônio.

${ }^{49}$ VENÂNCIO, Renato Pinto. Nos limites da sagrada família: ilegitimidade e casamento no Brasil Colonial. In: VAINFAS, Ronaldo (org.). História e sexualidade no Brasil. Rio de Janeiro: Graal, 1986, pp. 110-1.

50 BURMESTER, Ana Maria de O. Population de Curitiba au XVIII siècle. Montreal: Universidade de Montreal, Tese, Doutorado,. 1981: 140 e 148. Por enquanto, nada nos impede de generalizar estes números para a totalidade da população pobre da colônia, inclusive para as uniōes consensuais relativamente estáveis. 
${ }^{51}$ BACELLAR, Carlos de Almeida Prado. Os senhores da terra: familia e sistema sucessória entre os senhores de engenho do oeste paulista, 1765-1855. Campinas: Área de Publicações CMU/Unicamp, 1997, pp. 62 e 59.

52 SCHWARTZ. op. cit. 1999a, pp. 362 e 421.

${ }^{53}$ A partir das incursões bandeirantes, os tupis-guaranis que habitavam a região ou foram mortos, aprisionados ou fugiram para o sul. Tempos depois, o Paraná Ocidental foi ocupado pelos Crens (Caigangs e suas variedades) e pelos Gês (Botocudos). Esse processo tem uma história, muito bem contada por HEMMING, John. Os índios e a fronteira no Brasil Colonial. In: BETHEL, Leslie. História da América latina: A América Latina Colonial, vol. II. São Paulo: Edit. Da USP; Brasília, DF: Fundação Alexandre de Gusmão, 1999, p. 423 e seguintes.

${ }^{54}$ MARCÍLIO [op. cit., 1999:313] endossa o número de 2.431.000, contabilizado por John HEMMING em 1978. BOXER [op. cit. P. 306] não acredita que o número de ameríndios no Brasil possa ter sido maior do que 1 milhão. DENEVAN, pelo contrário, estima que somente os índios da Bacia Amazônica somassem entre 3,7 e 5 milhôes [BETHEL, Leslie. Notas sobre as populaçôes americanas às vésperas das invasões européias. In: . História da América latina: A América Latina Colonial, vol. II. São Paulo: Edit. Da USP; Brasília, DF: Fundação Alexandre de Gusmão, 1999. pp. 130-1].

${ }^{55}$ Foi, como qualifica Maria Luiza MARCÍLIO, um verdadeiro "holocausto" [OP. CIT., p. 1999:313-5]. ALENCASTRO chama a atenção para a coincidência entre a crescente importância do tráfico africano, a conseqüente diminuição da importância econômica do cativeiro dos índios, e o sistemático extermínio da população nativa. Cada vez mais, principalmente no que se referia às regiōes de expansão do gado, as populações indígenas constituíam um embaraço a ser eliminado [op. cit., pp. 336-7].

${ }^{56}$ BOXER, op. cit. p. 295.

${ }^{57} \mathrm{Na}$ prática, o índio passou a integrar de maneira complementar a mão-de-obra cativa, a partir da segunda metade do século XVIII [ALENCASTRO, op. cit. p. 339]. Ainda no século XIX, como presa de guerra [Carta Régia de 1808. Apud BALHANA, Altiva Pilatti et al. História do Paraná. Curitiba: Grafipar, 1969, p. 82].

${ }^{58}$ BOXER. op. cit. 304 e 294-299. MARCÍLIO, op. cit, 1999, p. 314-5. FREYRE, Gilberto. Casa-grande e senzala: formação da familia brasileira sob o regime da economia patriarcal. Rio de Janeiro: Record, 1997, pp. 154 e 157.

${ }^{59}$ MARCÍLIO. op. cit. 1999 , p. 319.

${ }^{60}$ BALHANA et al., op. cit., 1969, p. 75.

${ }^{61}$ Ver quadro 1 , anexo.

${ }^{62}$ IHGEB, 1868, apud DE BONI, op. cit., p. 23. Sobre as fontes de dados demográficos censitários para a história da população brasileira e respectivos comentários, ver em especial ALDEN, Dauril. O período final do Brasil Colônia, 1750-1808. In: BETHEL, Leslie. História da América latina: A América Latina Colonial, vol. II. São Paulo: Edit. da USP; Brasília, DF: Fundação Alexandre de Gusmão, 1999, pp. 528-540, GRAHAM, Douglas 
H. \& MERRICK, Thomas W. População e desenvolvimento econômico no Brasil. Rio de Janeiro: Zahar, 1981, pp. 45-51 e MARCÍLIO, op. cit. 1973.

${ }^{63} \mathrm{O}$ governador da capitania, D. Luis Antônio de Souza Botelho e Mourão, o Morgado de Mateus, informava, em 1776 que, "muitos moradores da Vila de Curitiba, atendendo às conveniências de sua acomodação [...] se têm ausentado de suas habitaçôes, desertando delas para os matos". Apud BALHANA et al., op. cit., 1969, p. 76. Uma crítica deste tipo de documentação tem de levar em conta, necessariamente, a possibilidade de subenumerações de membros adultos e solteiros dos domicílios.

${ }^{64}$ SOUZA. op. cit. 1979 , p. 36.

${ }^{65}$ FRANCO. op. cit.,p. 61.

${ }^{66}$ SOUZA. op. cit., 1986:144. Bem mais tarde, em 1776 e no contexto curitibano de Gregório e Anna Maria, somente 45 domicílios eram chefiados por mulheres (das quais, 38 eram viúvas com filhos), para um total de 434 unidades - ou seja, 10,4\%. Em 1785, esta proporção é praticamente a mesma: 10,8\%, representando 64 (61 de viúvas com filhos) domicílios em 595 [DE BONI, op. cit. p. 180].

${ }^{67}$ HOLANDA, Sérgio Buarque de. Caminhos e fronteiras. 2a ed. Rio de Janeiro: J. Olympio, 1975, pp. 12-40. Ainda, como descreve Antônio Cândido, "A combinação dos traços culturais indígenas e portugueses obedeceu ao ritmo nômade do bandeirante e do povoador, conservando as características de uma economia largamente permeada pelas práticas de presa $e$ coleta, cuja estrutura instável dependia da mobilidade dos individuos e dos grupos. Por isso, na habitação, na dieta, no caráter do caipira, gravou-se para sempre o provisório da aventura." [op. cit. 1979:37].

${ }^{68}$ Anna Maria foi batizada na capella do Senhor bom Jesus dos Perdōes, da freguesia de Curitiba, em 2 de março de 1752. Pais e padrinhos eram moradores do bairro de São José, onde se localizava a capela. Batismo . Livro 2 (1731[28]-1756[72]). Acervo do Arquivo da Catedral Basílica Menor Nossa Senhora da Luz dos Pinhais de Curitiba.

${ }^{69} \mathrm{O}$ processo que resultou nos proclamas do casamento contém a informação do Vigário da Paróquia Nossa Senhora do Pilar sobre o batismo de Gregório (17 de maio de 1749) [Microfilme do acervo do Centro de Documentação e Pesquisa da História dos Domínios Portugueses, Departamento de História, UFPR]. Os recenseamentos de 1801 e 1803, relativos à Segunda Companhia de Ordenança de Curitiba, confirmam que Gregório Gonçalves era oriundo da Vila de Antonina [LUI, Eduard Henry. Bastardia e marginalidade social; Curitiba, século XVIII. Curitiba, 2002. Monografia, Curso de História, Universidade Federal do Paraná, 2002, p. 43].

${ }^{70}$ Bairros de Butiatuva, Tinguiquera, Distrito de Roberto Cardozo, Povoação de Nossa Senhora do Amparo, e bairro do Itaperuçú [LUI, 2002:56 - Ver de novo a tabela 1, anexa].

${ }^{71}$ BACELLAR. op. cit., p. 2000:8.

${ }^{72}$ Apud BALHANA et al., op. cit., 1969, p. 74-5.

${ }^{73}$ É preciso, entretanto, destacar que Anna Maria era oriunda da freguesia de São José. Pelo que se depreende, seus moradores eram mais pobres do que os que tinham sítio em 
Curitiba. A respeito deles, a Câmara de Curitiba destacava que, "obrigados da necessidade de se alimentarem, é querivel a diligência que terão em plantar para comer, e contudo é constante que nunca tiveram de seus frutos com que passar o ano, vivendo comumente das farinhas de Paranaguá, e por isso os que podem lavram nas faisqueiras do arraial e na conconha para ela e para o Rio de São Francisco".

${ }^{74}$ Sobre os diversos recursos alimentares dos "paulistas" nos séculos XVII e XVIII, ver HOLLANDA. op. cit. 1975 e SOUZA, op. cit. 1979.

${ }^{75}$ SCHWARTZ. 1999a: op. cit. p. 418.

${ }^{76}$ É muito provável que, nas zonas de agricultura mista, baseada no trabalho familiar livre, as taxas de fecundidade eram maiores do que para os casais de status semelhante que viviam nas zonas de agricultura monocultora de exportação, operadas por mão-de-obra escrava. MARCÍLIO, op. cit., 1999:324.

77 BALHANA, op. cit., p. 88 e 91.

${ }^{78} \mathrm{O}$ termo "tropeiro" exige uma precisão: dentro da categoria, é possível distinguir o comerciante e proprietário do gado, dos condutores das tropas. Para aprofundar, ver FRANCO, 1997, op. cit. 71.

${ }^{79} \mathrm{O}$ exemplo da Lapa, tradicional celeiro de tropeiros no Paraná, é sintomático. Os gráficos relativos à distribuição sazonal dos casamentos mostram uma freqüência diminuta de matrimônios durante parte do ano. CARDOSO, Jayme Antônio \& NADALIN, Sergio Odilon. Os meses e os dias de casamento no Paraná - séculos XVIII, XIX e XX. História: questôes \& debates, 3(5):dez. 1982, p. 61-2.

${ }^{80}$ Cf. SOUZA, op. cit. 1979:76-7.

${ }^{81} \mathrm{Ver}$, novamente, as possíveis indicações na tabela 1 .

${ }^{82}$ SOUZA. op. cit. 1979 , p. 76.

${ }^{83}$ BURMESTER. op. cit. 1981.

${ }^{84}$ MARCÍLIO. 1986:174.

${ }^{85}$ BURMESTER. op. cit., 1981, p. 250.

${ }^{86}$ Óbitos. Livro 5 (1823-1838[41], destinado a "brancos, bastardos e escravos"): "Aos quinze dias do mês de setembro do anno de mil oitocentos e vinte e cinco faleceo da vida prezente Anna Maria de Lima de idade de oitenta annos casada com Gregório Gonçalves [...]"

${ }^{87}$ Óbitos, Livro 6 (1839[18]-1856, destinado a todas as categorias), 29 de abril de 1844 e 18 de abril de 1843, respectivamente. No primeiro registro consta o falecimento de "Gregório Gonçalves viuvo de idade de cem anos". A correção para 95 anos tem como fundamento o ano do batismo, provavelmente ano do nascimento (ver tabela anexa).

${ }^{88}$ Trata-se de duas marcas possíveis, a partir do estudo realizado por BURMESTER [op. cit. 1981, p. 197 e seguintes], referindo-se à parcela mais "estável" da população curitibana. Deduz, a partir destes dados, a esperança de vida ao nascer. A relativa amplitude das probabilidades de morte nos libera para algumas generalizações.

${ }^{89}$ BOXER. op. cit. p. 206. 
${ }^{90}$ NADALIN, op. cit., 1994, P. 85.

${ }^{91}$ MARCÍlIO, op. cit. 1984:199.

92 SCHWARTZ, op. cit., 1999a, pp. 341, 347-8, p. 350.

${ }^{93}$ Idem (MARCÍLIO, op. cit. ,1984, p. 199).

${ }^{94}$ PRADO JR., op. cit. 1996, p. 286.

${ }^{95}$ SOUZA, op. cit., 1986, p. 63.

${ }^{96}$ MARCÍlIO, op. cit. 1999, p. 326; 335.

${ }^{97}$ MELLO, Pedro Carvalho de. 1975. Apud GRAHAM \& MERRICK, op. cit. p.83. Sua data base, 1872, extrapola a data baliza deste artigo. Igualmente para este período, "Robert Slenes estimou que e expectativa de vida ao nascer [...] era entre 19 e 27 anos para os escravos brasileiros em fins do século XIX, número esse um pouco menos do que os 27,08 calculados para a população brasileira como um todo em 1879" [SCWARTZ, Stuart B Segredos internos; engenhos e escravos na sociedade colonial, 1550-1835. São Paulo: Cia. das Letras, 1999b, p. 303].

${ }^{98}$ GRAHAM \& MERRICK, op. cit., p. 84-6. SCWARTZ, op. cit. 1999 b, pp. 314 e 318. ${ }^{99}$ BOXER, op. cit. 198.

${ }^{100}$ GRAHAM \& MERRICK, op. cit. p. 55. Ver também SCHWARTZ, op. cit. p. 1999a, p. 354 .

${ }^{101}$ SCHWARTZ, op. cit. 1999 b,p. 298.

102 GRAHAM \& MERRICK, op. cit. 81. Essas evidências são grifadas pelo autor, num contexto comparativo entre os regimes demográficos nos Estados Unidos e no Brasil.

${ }^{103}$ Alguns autores trocam os termos de causa e efeito. Por exemplo, BOXER conclui que "sendo sua mortalidade tão alta e sua natalidade tão baixa, resultava daí uma rápida renovação de escravos, o que, por sua vez, determinava grande procura junto às reservas do mercado de escravos com a Africa Ocidental." [op. cit. p. 198]. Apesar das dificuldades para estimar os números relativos ao tráfico de escravos africanos, calcula-se que, no século XVII, foram "importados" entre 200 mil (posição mais conservadora) e 700 mil. Para o século XVIII, ingressaram de 2,2 a 2,5 milhōes. MARCÍLIO, op. cit. 1999, pp. 328-9. CURTIN, Phillip D. (1969) apud. GRAHAM \& MERRICK, aponta as seguintes cifras: 50 mil no primeiro século, 560 mil no século XVII, 1.891,4 mil no XVIII (até 1810) e 1.145,4 mil entre 1811 e 1870 [op. cit. 1981, p. 75].

${ }^{104}$ MARCÍLIO, op. cit., 1999, pp. 329-30; SCHWARTZ, op. cit., 1999b, pp. 296-7.

105 "O equilibrio entre nascimentos e mortes nas áreas rurais foi provavelmente mais constante, embora fosse afetado pela mortalidade relativamente elevada da população escrava”. GRAHAM \& MERRICK, op. cit. 1981, p. 57.

${ }^{106}$ GRAHAM \& MERRICK, op. cit. 1981, pp. 90-2.

${ }^{107}$ MARCÍLIO, op. cit. 1984, p. 201.

${ }^{108}$ Sobre a expressividade das cidades coloniais, ver MARCÍLIO, op. cit., 1999, p. 333-4;

SCHWARTZ, op. cit. ,1999a, 403. 
${ }^{109}$ RUSSELL-WOOD, A.J.R. O Brasil Colonial: o ciclo do ouro, 1690-1750. In: BETHEL, Leslie. História da América latina: A América Latina Colonial, vol. II. São Paulo: Edit. Da USP; Brasília, DF: Fundação Alexandre de Gusmão, 1999, p. 522.

${ }^{110}$ GRAHAM \& MERRICK, op. cit., p. 57.

${ }^{111}$ NADALIN, op. cit., p. 88-9. Apesar das diferenças de altitude não serem tão marcantes, é possível incluir nessa reflexão o isolamento relativo do núcleo de São Paulo de Piratininga do litoral, pela mesma serra.

${ }^{112}$ Não posso deixar de reconhecer que estou sendo influenciado por Malthus. Ver também, a esse respeito, as considerações feitas por ROWLAND [s.d.].

${ }^{113}$ MARCÍLIO, op cit., 1984, p. 198. GRAHAM \& MERRICK aceitam - implicitamente - como razoável uma taxa de 1,2\% ao ano [op. cit.,1981, pp. 48-51].

${ }^{114}$ BELTRÃO, Pedro Calderan. Demografia, ciência da população: análise e teoria. Porto Alegre: Sulina, 1972. p. 171.

115 BRIGNOLI, Hector Pérez. El crescimiento demografico de America Latina en los siglos XIX y XX: problemas, metodos y perspectivas (Paper inédito, de comunicação apresentada no Congresso sobre a história da população da América Latina, Ouro Preto, julho de 1989, p. 2.

${ }^{116}$ Uma das questões bem estudadas tem como referência a problemática do "Antigo Regime Demográfico", cujas evidências empíricas apontam para a nupcialidade como um componente explicativo fundamental: "é a mortalidade que, através dos seus efeitos sobre a nupcialidade, regula o nivel da fecundidade” [ROWLAND, (s/d)].

117 Cf. HOLANDA, Sérgio Buarque de. Raizes do Brasil. 4ª ed. Rio de Janeiro: José Olympio, 1963.

${ }^{118}$ Inspira essas questões TORRES-LONDOÑO, op. cit., pp. 31-46. De modo igual, VAINFAS, op. cit. p. 49 e seguintes.

${ }^{119}$ REINHARD, Marcel R. et al. Histoire générale de la population mondiale. Paris: Montchrestien, 1968, pp. 672-3.

${ }^{120}$ OLIVEIRA VIANNA, V.1, op. cit. p. 101.

${ }^{121}$ GOLDSCHMIDT, Eliana. (Verbete:) Prostituição. In: SILVA, Maria Beatriz Nizza da (org.). Dicionário da história da colonização portuguesa no Brasil. Lisboa: Verbo, 1994. Pp. 669-72.

${ }^{122}$ Refiro-me às contradições no crescimento da população colonial, uma vez que há um certo consenso em torno de taxas de aumento global da população da América Portuguesa, que não teriam sido nunca inferiores a 1\% ao ano [MARCÍLIO, op. cit. 1984, p. 198].

${ }^{123}$ TORRES-LONDOÑO, op. cit. pp.159-194.

${ }^{124}$ MACHADO, 1985:17.

${ }^{125}$ HOLANDA, 1966:55. NA ausência de evidências empíricas, devo pelo menos registrar o entusiasmo de OLIVEIRA VIANNA pela "incomparável fecundidade" dos paulistas, "que cria a necessidade de emigraçôes contínuas e numerosas. [...] São as bandeiras que 
descarregam os latifúndios do seu excesso humano [...]. Durante dois séculos, esses pequenos centros sociais de S. Vicente, S. Paulo, Taubaté, Guaratinguetá, Mogi das Cruzes, contaminam todo o Brasil meridional e central, sem que dos seus celeiros demográficos se esgotem as reservas povoadoras" [V.1, op. cit. 1952:130].

${ }^{126}$ Idem, Ibidem, v.1, 1952:113.

${ }^{127}$ Existe uma relação entre a importação de escravos e a mortalidade: em tese, quanto maior a quantidade de escravos, menor o seu custo; em conseqüência, menor o cuidado com a escravaria e maior a morbidade/mortalidade. Da mesma forma, deve haver uma relação inversa entre o fluxo da entrada de escravos e a fecundidade.

${ }^{128}$ Ver SCHWARTZ, op. cit. 1999a, p. 356;op. cit. 1999b, pp. 286-92; 296-303.

${ }^{129}$ A esse respeito, ver FLORENTINO, Manolo \& GÓES, José Roberto. A paz das senzalas. Familias escravas e tráfico atlântico, Rio de Janeiro, c. 1790-c. 1850. Rio de Janeiro: Civ. Brasileira, 1997, pp. 113-25.

${ }^{130}$ BACELLAR, op. cit. 1997, pp. 75-6; 88; 97-8. Um quadro completo dos comportamentos matrimoniais da elite paulista, eventualmente extrapolável para outras regiōes da colônia, foi construído por NAZZARI, Muriel. O desaparecimento do dote. Mulheres, famílias e mudança em São Paulo, Brasil, 1600-1900. São Paulo: Cia. das Letras, 2001.

${ }^{131}$ VIEIRA JR., Antonio Otaviano. A familia na Seara dos sentidos: domicílio e violência no Ceará (1780-1850). São Paulo, Universidade de São Paulo, Tese de Doutorado, 2002, em especial a primeira parte da tese (pp. 01-133).

${ }^{132}$ Ver RUSSELL-WOOD, op. cit., 1999, p. 522.

\section{Resumo}

O artigo apresenta diretrizes teóricas da história da população da América lusa colonial tendo como eixo narrativo - sem resvalar numa história regional - os habitantes dos campos paranaenses, no quadro cronológico do século XVIII. Palavras-chave: América portuguesa colonial; história demográfica.

\section{Abstract}

The article presents the theoretical main lines of the history of portuguese colonial America's population with a narrative axis not based on regional history but on the history of the inhabitants Parana's fields, during the XVIIIth century. Key-words: Portuguese colonial America; demographic history. 